Research Article

\title{
Repairing and Strengthening of Damaged RC Columns Using Thin Concrete Jacketing
}

\author{
Bassam A. Tayeh, Mohammed Abu Naja, Samir Shihada, and Mohammed Arafa
}

Civil Engineering Department, Islamic University of Gaza, Gaza, State of Palestine

Correspondence should be addressed to Mohammed Arafa; marafa@iugaza.edu.ps

Received 28 January 2019; Revised 29 April 2019; Accepted 8 May 2019; Published 11 June 2019

Academic Editor: Chiara Bedon

Copyright (c) 2019 Bassam A. Tayeh et al. This is an open access article distributed under the Creative Commons Attribution License, which permits unrestricted use, distribution, and reproduction in any medium, provided the original work is properly cited.

\begin{abstract}
This research aims to investigate the efficiency of repairing damaged concrete columns using thin concrete jacketing. The experimental program included casting of nine reference $300 \mathrm{~mm}$ long reinforced concrete column specimens: three specimens had a cross-sectional dimension of $100 \mathrm{~mm} \times 100 \mathrm{~mm}$, three specimens had a cross-sectional dimension of $150 \mathrm{~mm} \times 150 \mathrm{~mm}$, and three specimens had a cross-sectional dimension of $170 \mathrm{~mm} \times 170 \mathrm{~mm}$. A total of 36 identical column cores were cast with similar cross sections of $100 \mathrm{~mm} \times 100 \mathrm{~mm}$ and a height of $300 \mathrm{~mm}$. These cores were damaged by loading them with approximately $90 \%$ of their actual ultimate axial load capacities. Then, the columns were repaired and strengthened by applying two jacketing materials, which were 25 and $35 \mathrm{~mm}$ thick, on all four sides. Group 1 consisted of 18 column cores jacketed by normal strength concrete with a maximum aggregate size of $4.75 \mathrm{~mm}$ and steel reinforcement, whereas Group 2 consisted of 18 column cores jacketed using ultrahigh-performance fibre-reinforced self-compacting concrete with steel reinforcement. The experimental program showed that the Group 1 specimens had ultimate load capacities more than twice those of the unjacketed reference columns and the same axial capacity as the monolithically cast reference columns. The Group 2 specimens showed a significant increase in ultimate load capacity, which was approximately 3 times that of the unjacketed reference column and 1.86 times that of the monolithically cast reference columns. Moreover, using the shear studs was found to be the most effective among the three surface preparation techniques.
\end{abstract}

\section{Introduction}

The repair and rehabilitation of existing structures are major construction activities. Meanwhile, reinforced concrete (RC) is used widely as a construction material in most parts of the world. Structures made with this material often suffer damages due to overloading, natural disasters (e.g., earthquake and flood), fire, environmental effects (e.g., corrosion), or changes in building usage before reaching their intended design life. These damages may cause the structural elements to fail to meet the functional requirements within their designed service life. If proper attention is not paid in this regard, structures could fail to carry their design load and disasters could occur [1].

The failure of the most important structural elements, i.e., columns, may lead to the total collapse of frame- structured buildings because they are the only structural elements that convey the total vertical loads of buildings to the soil. These members can lose their strength and stiffness due to damages during their service lives. Therefore, repair or reconstruction is necessary in case of noticeable cracks to ensure that loads are further carried and transmitted to the soil [2].

Strengthening methods depend on the type of structure and loading. Regarding structures subjected primarily to static loads, increasing flexural and axial compressive strength is essential. Regarding structures subjected primarily to dynamic loads, increasing flexural and shear strength is crucial. Improving column ductility and rearranging column stiffness can also be achieved with strengthening methods. Damages to RC columns may include slight cracks without damage to reinforcement, 
superficial damage in concrete without damage to reinforcement, concrete crushing, reinforcement buckling, or tie rupture. On the basis of the degree of damages, techniques such as injections, removal and replacement, or jacketing can be applied [3-8]. Three principal techniques are available for strengthening $\mathrm{RC}$ columns: concrete jacketing, steel jacketing, and composite jacketing (FRP) [1].

The susceptibility of existing buildings to structural damages largely depends on the quality of the design, detailing, and construction. Engineers in many cases can extend the life span of buildings by utilising simple repairing or strengthening techniques. The choice of repairing or strengthening techniques becomes, therefore, the decisive factor because high costs may prevent many building owners from executing essential repair works [9-13].

Experimental investigations into strengthened or repaired columns are generally conducted on unloaded original columns, although having unloaded strengthened columns in the field presents a challenge. In studying the behaviour of strengthened columns with preloading, the original column is important but difficult to apply experimentally [3, 14-16].

Ersoy et al. [17] studied the repairing and strengthening of columns by jacketing. They tested four basic columns with identical dimensions and reinforcement under monotonic axial loading. After the test, they jacketed and retested these basic columns. They called the intervention either a repairing or strengthening jacket depending on whether the basic specimens had been loaded to a damaged level.

Fukuyama et al. [2] investigated jacketing with RC steel plates and carbon fibre sheets. This method has been widely used to repair or strengthen the RC columns damaged by the Hyogoken-Nanbu earthquake in 1995. To investigate the shear strength and ductility of RC columns repaired or strengthened by jacketing, they tested eight column specimens under constant axial compressive load and cyclic shear forces.

Meda et al. [7] studied the possibility of strengthening existing RC columns with a technique based on the application of a high-performance fibre-reinforced concrete jacket with $170 \mathrm{MPa}$ compressive strength.

The ultrahigh-performance fibre concrete with a compressive strength of more than $100 \mathrm{MPa}$ and improved durability marks an advancement in the concrete industry. This high-performance material offers various interesting applications. It allows the construction of sustainable and economic buildings with an extraordinary slim design. Its high strength and ductility make it the ultimate building material, e.g., for bridge decks, storage halls, thin-walled shell structures, and highly loaded columns. Aside from its improved strength properties, its outstanding resistance against all kinds of corrosions is an additional milestone on the way towards zero-maintenance construction [18-21].

Many researchers have investigated the bond strength between two concrete layers and different techniques for increasing the roughness of the substrate surface [22-28].

Nowadays, repairing techniques suitable in terms of low cost and fast execution time should be identified. Hence, the current research studied the repairing and strengthening of square RC columns by applying two concrete jacketing types: using ultrahigh-performance fibre-reinforced selfcompacting concrete (UHPFRSCC) and normal strength concrete (NSC) as jacketing materials with three methods of surface roughening, i.e., mechanical wire brushing, mechanical scarification, and using shear studs. Moreover, the effects of jacket thickness on ultimate load-carrying capacity and axial displacement were studied. The obtained results were compared with those of the reference columns. The bonding among the column cores with their jacketing was investigated to decide on the best surface preparation technique.

\section{Experimental Program}

The experimental work herein aims to investigate the bonding among the column cores and their jacketing and the ultimate load-carrying capacity and axial displacement of uniaxial loaded square RC columns repaired and strengthened using two jacketing types with three methods of surface roughening. The obtained results are compared with those of the reference columns. Figure 1 presents the experimental plan of column specimens' fabrication.

2.1. Fabrication of Column Specimens. The current study includes the fabrication of 45 column specimens: 9 column specimens are reference columns, whereas 36 column cores are repaired and strengthened by applying two jacketing types using NSC-4.75 and UHPFRSCC with three methods of surface roughening. All column specimens are designed according to ACI 318 code requirements [25]. The longitudinal reinforcement ratio of all column specimens is not less than $1 \%$. The details of the fabricated column specimens are as follows:

(1) Three square column specimens (UC) are cast monolithically to act as unjacketed reference columns (similar to the column core). These reference columns have cross-sectional dimensions of $100 \mathrm{~mm} \times 100 \mathrm{~mm}$ and a height of $300 \mathrm{~mm}$ with $4 \varnothing 8 \mathrm{~mm}$ longitudinal steel reinforcement and $3 \varnothing 2.5 \mathrm{~mm}$ steel reinforcement ties, as shown in Figure 2.

(2) Six square column specimens (MC1 and MC2) are cast monolithically as reference columns. These reference columns have cross-sectional dimensions of $150 \mathrm{~mm} \times 150 \mathrm{~mm}$ and $170 \mathrm{~mm} \times 170 \mathrm{~mm}$ and a height of $300 \mathrm{~mm}$ with $4 \varnothing 8 \mathrm{~mm}$ longitudinal steel reinforcement and $3 \varnothing 2.5 \mathrm{~mm}$ steel reinforcement ties (Figure 3).

(3) All the column specimens which are jacketed are loaded with approximately $90 \%$ of their actual axial capacity and are associated with appearing hairline cracks without reaching failure.

(4) Two jacketing types are applied to two groups of column cores (A-B and X-Y). The first group (A-B) consists of 18 column cores jacketed with NSC-4.75 


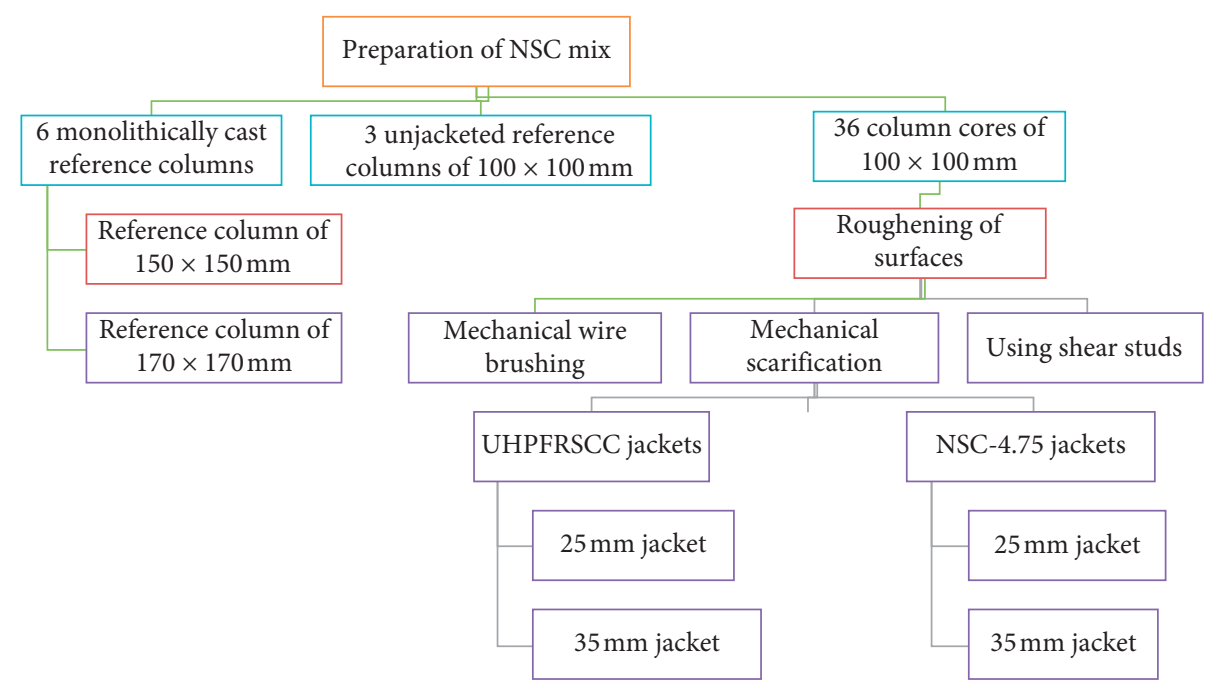

FIgURE 1: Experimental program.

using additional longitudinal and transverse steel reinforcement. The contact surfaces between the old and new concrete are roughened by three methods, i.e., mechanical wire brushing, mechanical scarification, and using shear studs. The second group (XY) consists of 18 column cores jacketed with UHPFRSCC using additional steel reinforcement. The surfaces are roughened in a similar way to the first group.

(5) Two jacket thicknesses of 25 and $35 \mathrm{~mm}$ are applied to the two groups of column cores (A-B and X-Y).

(6) The overall cross-sectional dimensions of the A-B and $\mathrm{X}-\mathrm{Y}$ jacketed column specimens become $150 \mathrm{~mm} \times 150 \mathrm{~mm}$ and $170 \mathrm{~mm} \times 170 \mathrm{~mm}$ with jacket thicknesses of 25 and $35 \mathrm{~mm}$, respectively, and fixed heights of $300 \mathrm{~mm}$.

(7) The test result for the column specimens is considered the average of the three samples (S1, S2, and S3). Table 1 shows the details of the 45 column specimens considered in the experimental program.

2.2. Types of Concrete Mixes. In this research, the following concrete mixes are designed on the basis of the targeted concrete compressive strength.

2.2.1. NSC. The NSC mix is prepared and used to cast the UC reference columns, MC reference columns, and the column cores of the two groups A-B and X-Y. Table 2 shows the NSC mixing proportions.

2.2.2. NSC-4.75. The NSC mix with a maximum aggregate size of $4.75 \mathrm{~mm}$ (NSC-4.75) is prepared and used to cast the jackets of the A-B column specimens. The absolute volume method recommended in $[29,30]$ is used to compute the quantities of concrete materials required for the NSC-4.75 mix. Table 3 shows the mixing proportions of NSC-4.75.
2.2.3. UHPFRSCC. The UHPFRSCC mix is used to cast the jacket of the X-Y column specimens. It is prepared using the ingredients detailed in Table 4 [31]. The UHPFRSCC mix is designed to obtain a target standard cylinder compressive strength of approximately $120 \mathrm{MPa}$. The UHPFRSCC mix is prepared at IUG Soil and Materials Laboratory. All required amounts of constituent materials are weighed accurately and mixed properly using a tilting revolving drum mixer to produce homogeneous concrete. The mixing procedures are based on the study in [32].

2.3. Preparation of UC and MC Reference Columns and Column Cores. The NSC mix is prepared to obtain a targeted standard cylinder compressive strength of approximately $25 \mathrm{MPa}$. The low targeted strength represents the real status of most damaged RC columns. The absolute volume method recommended in [29] is used to compute the quantities of concrete materials required for the NSC mix.

The UC and MC reference columns and A-B and X-Y column cores are reinforced with two types of steelreinforcing bars. High tensile strength steel with a yield stress of $360 \mathrm{MPa}$ is used for longitudinal steel reinforcement, whereas steel reinforcement ties with a yield stress of $240 \mathrm{MPa}$ are used. Tests are carried out for each bar size: three steel specimens with a diameter of $8 \mathrm{~mm}$ and length of $300 \mathrm{~mm}$ and another three steel specimens with a diameter of $2.5 \mathrm{~mm}$ and length of $280 \mathrm{~mm}$. All steel samples are obtained from randomly chosen bars. Table 5 shows the testing results of the main longitudinal and transverse steel reinforcements.

2.4. Preparation of Jackets. Two jacketing types are applied to the two groups of column cores, i.e., A-B and X-Y. The A-B group represents the 18 column cores jacketed by NSC with a maximum aggregate size of $4.75 \mathrm{~mm}$ (NSC-4.75); the steel reinforcement cage is placed in the jacket. The $\mathrm{X}-\mathrm{Y}$ group represents the 18 column cores jacketed by UHPFRSCC; the steel reinforcement cage is placed in the jacket. 


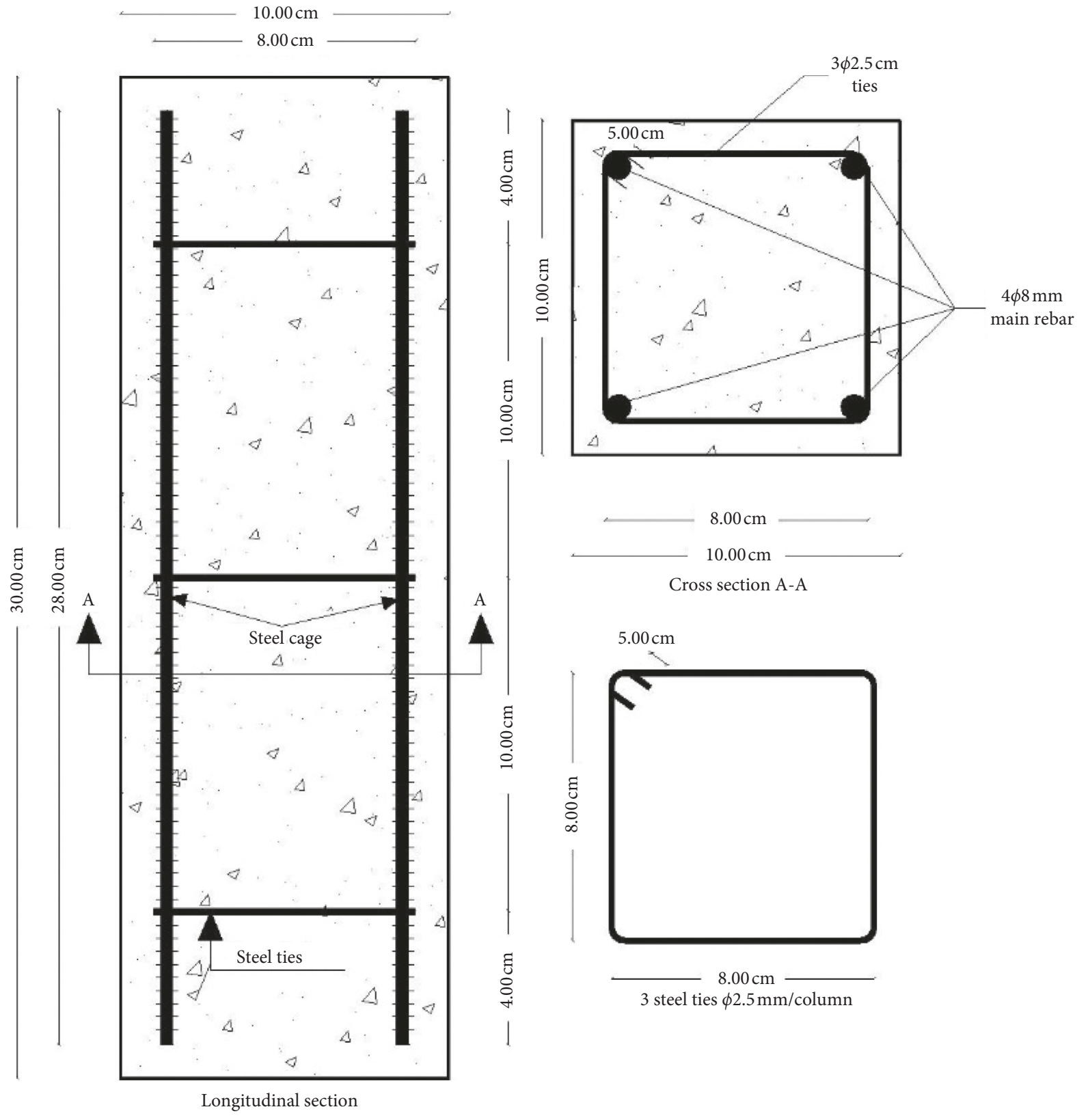

FIGURE 2: Geometry and reinforcement details of UC unjacketed reference columns.

2.4.1. Preparation of Core Surfaces. Three methods are used to roughen the surfaces of column cores to investigate the method which can provide the best bond between column cores and their jacketing.

(1) Preparation of $A-B-W$ and $X-Y-W$ Groups. Using mechanical wire brushing, the specimens' surfaces are cleaned to remove the dust and ensure their roughness. Figure 4 shows the preparation of the $\mathrm{A}-\mathrm{B}-\mathrm{W}$ and $\mathrm{X}-\mathrm{Y}-\mathrm{W}$ groups [33]. $4 \varnothing 8 \mathrm{~mm}$ main steel-reinforcing bars with a length of $280 \mathrm{~mm}$ and a diameter of $8 \mathrm{~mm}$ are used at the four corners of the column cores. $3 \varnothing 2.5 \mathrm{~mm}$ transverse steel reinforcement ties are used and fixed to the longitudinal steel bars (not welded) with a vertical spacing of $90 \mathrm{~mm}$.
(2) Preparation of $A-B-C$ and $X-Y-C$ Groups. In preparing the core surfaces of the $\mathrm{A}-\mathrm{B}-\mathrm{C}$ and $\mathrm{X}-\mathrm{Y}-\mathrm{C}$ groups, a concrete cutting diskette is used to scarify the specimens' surfaces. The scarification is approximately $3-6 \mathrm{~mm}$ wide and 5$7 \mathrm{~mm}$ deep for good roughening. Figure 5 shows the preparation of the A-B-C and X-Y-C groups [33]. $4 \varnothing 8 \mathrm{~mm}$ main steel-reinforcing bars with a length of $280 \mathrm{~mm}$ and a diameter of $8 \mathrm{~mm}$ are used at the four corners of the column cores. Figures 6 and 7 show the geometry and reinforcement detailing of the A-C and B-C groups, respectively. The geometry and steel detailing of the Y-W, B-C, and Y-C groups are discussed later. $3 \varnothing 2.5 \mathrm{~mm}$ transverse steel reinforcement ties are used and fixed to the longitudinal steel bars (not welded) with a vertical spacing of $90 \mathrm{~mm}$. 

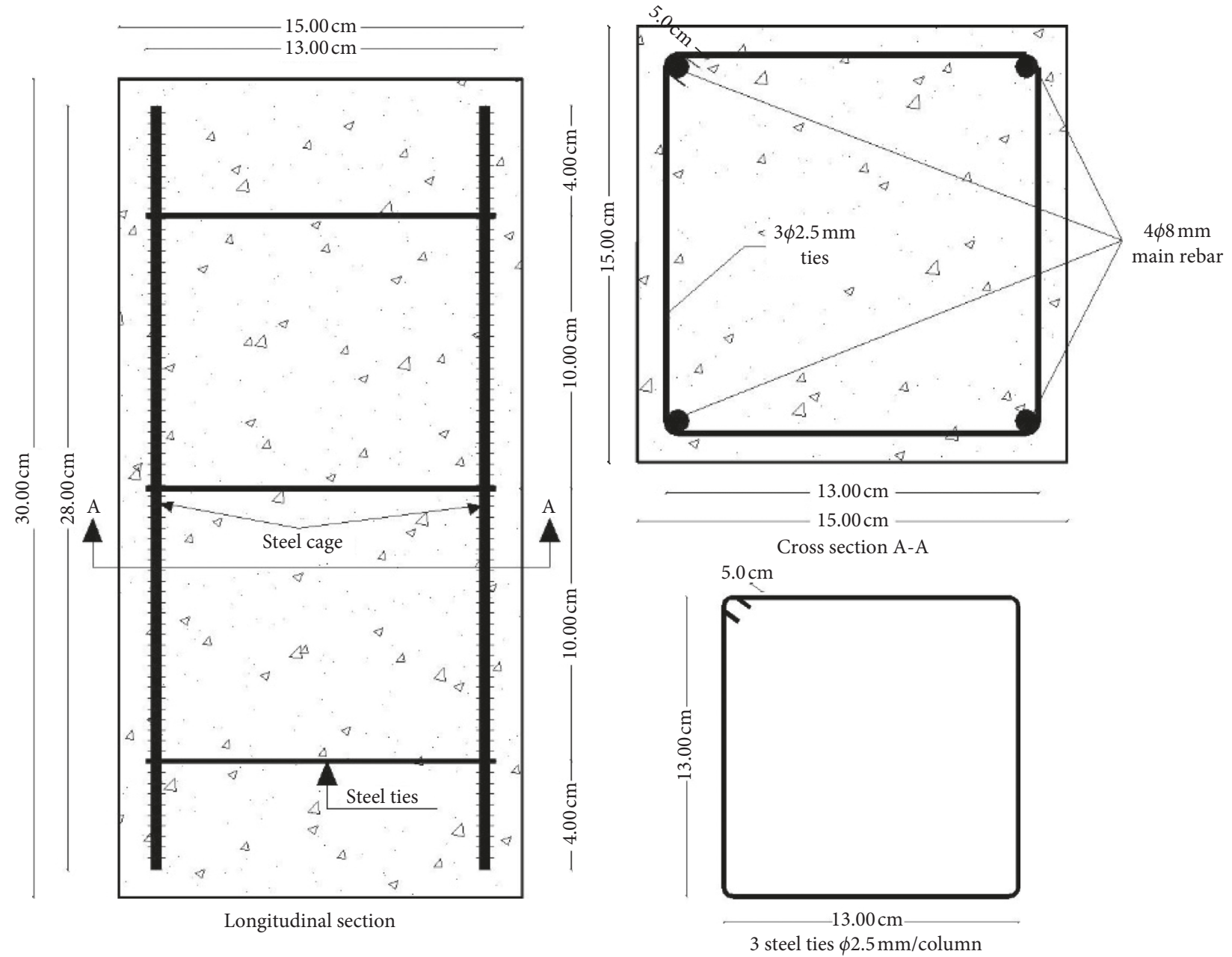

FIGURE 3: Geometry and reinforcement details of MC1 unjacketed reference columns.

TABle 1: Details of column specimens.

\begin{tabular}{|c|c|c|c|c|c|c|c|}
\hline \# & & Description & Notation & $\begin{array}{l}\text { Column core } \\
\qquad(\mathrm{mm})\end{array}$ & $\begin{array}{l}\text { Overall cross } \\
\text { section }(\mathrm{mm})\end{array}$ & $\begin{array}{c}\text { Jacket } \\
\text { thickness } \\
(\mathrm{mm}) \\
\end{array}$ & $\begin{array}{l}\text { Number of } \\
\text { samples }\end{array}$ \\
\hline 1 & \multirow{3}{*}{\multicolumn{2}{|c|}{ MC monolithically cast reference columns }} & UC & $100 \times 100$ & \multirow{3}{*}{\multicolumn{2}{|c|}{$\begin{array}{l}\text { Cross-sectional dimensions of UC } \\
\text { and MC reference columns are fixed }\end{array}$}} & 3 \\
\hline 2 & & & MC1 & $150 \times 150$ & & & 3 \\
\hline 3 & & & MC2 & $170 \times 170$ & & & 3 \\
\hline 4 & \multirow{6}{*}{$\begin{array}{c}\text { NSC-4.75 jacket, } \\
{[\mathrm{A}-\mathrm{B}]}\end{array}$} & \multirow{4}{*}{$\begin{array}{l}\text { Roughening surface by } \\
\text { mechanical wire brushing } \\
\text { Roughening surface by } \\
\text { mechanical scarification }\end{array}$} & A-W & $100 \times 100$ & $150 \times 150$ & 25 & 3 \\
\hline 5 & & & B-W & $100 \times 100$ & $170 \times 170$ & 35 & 3 \\
\hline 6 & & & $\mathrm{~A}-\mathrm{C}$ & $100 \times 100$ & $150 \times 150$ & 25 & 3 \\
\hline 7 & & & B-C & $100 \times 100$ & $170 \times 170$ & 35 & 3 \\
\hline 8 & & \multirow{2}{*}{ Bonding by using shear studs } & A-S & $100 \times 100$ & $150 \times 150$ & 25 & 3 \\
\hline 9 & & & B-S & $100 \times 100$ & $170 \times 170$ & 35 & 3 \\
\hline 10 & \multirow{6}{*}{$\begin{array}{l}\text { UHPFRSCC } \\
\text { jacket, }[\mathrm{X}-\mathrm{Y}]\end{array}$} & \multirow{4}{*}{$\begin{array}{l}\text { Roughening surface by } \\
\text { mechanical wire brushing } \\
\text { Roughening surface by } \\
\text { mechanical scarification }\end{array}$} & X-W & $100 \times 100$ & $150 \times 150$ & 25 & 3 \\
\hline 11 & & & Y-W & $100 \times 100$ & $170 \times 170$ & 35 & 3 \\
\hline 12 & & & $\mathrm{X}-\mathrm{C}$ & $100 \times 100$ & $150 \times 150$ & 25 & 3 \\
\hline 13 & & & $\mathrm{Y}-\mathrm{C}$ & $100 \times 100$ & $170 \times 170$ & 35 & 3 \\
\hline 14 & & \multirow{2}{*}{ Bonding by using shear studs } & X-S & $100 \times 100$ & $150 \times 150$ & 25 & 3 \\
\hline 15 & & & Y-S & $100 \times 100$ & $170 \times 170$ & 35 & 3 \\
\hline
\end{tabular}

(3) Preparation of $A-B-S$ and $X-Y-S$ Groups. Mechanical drilling with a $6 \mathrm{~mm}$ diameter drilling bit is conducted to perforate a hole with a diameter of $6 \mathrm{~mm}$ and a depth of
$25 \mathrm{~mm}$ in accordance with the ASTM A307 standards. The drilled holes are filled with the Sikadur-31 CF bonding material (SIKA Company) to ensure a good bond between 
TABLE 2: NSC mixing proportions.

\begin{tabular}{lc}
\hline Material & $\mathrm{kg} / \mathrm{m}^{3}$ \\
\hline Coarse aggregate & 1317 \\
Fine aggregate (sand) & 658 \\
Cement & 300 \\
Water & 165 \\
\hline
\end{tabular}

TABLE 3: NSC-4.75 mixing proportions.

\begin{tabular}{lc}
\hline Material & $\mathrm{kg} / \mathrm{m}^{3}$ \\
\hline Coarse aggregate & 1316.8 \\
Fine aggregate (sand) & 658.4 \\
Cement & 300 \\
Water & 165 \\
Superplasticizer & 9 \\
\hline
\end{tabular}

TABLE 4: UHPFRSCC mixing proportions [31].

\begin{tabular}{lc}
\hline Material & $\mathrm{kg} / \mathrm{m}^{3}$ \\
\hline Cement CEM I 42.5 R & 900 \\
Water & 216 \\
Silica fume & 90 \\
Quartz sand & 1125 \\
Superplasticizer & 27 \\
Steel fibres & 36 \\
\hline
\end{tabular}

the shear connectors and old concrete. L-shaped shear connectors with a diameter of $4 \mathrm{~mm}$ and a total length of $40 \mathrm{~mm}$ are used. The $25 \mathrm{~mm}$ straight portion of the shear connector is inserted in the drilled hole. Figure 8 shows the preparation of the A-B-S and X-Y-S groups. $4 \varnothing 8 \mathrm{~mm}$ main steel-reinforcing bars with a length of $280 \mathrm{~mm}$ and a diameter of $8 \mathrm{~mm}$ are used at the four corners of the column cores. Figures 9 and 10 show the geometry and reinforcement detailing of the A-S and B-S groups, respectively. The geometry and steel detailing of the X-S and Y-S groups are discussed later. $3 \varnothing 2.5 \mathrm{~mm}$ transverse reinforcement ties are used and fixed to the longitudinal steel bars (not welded) with a vertical spacing of $90 \mathrm{~mm}$.

2.4.2. Jacketing Using NSC-4.75. The mixing procedure comprises the following steps [34]: The NSC- 4.75 concrete is placed in timber moulds. Three standard test cylinders with a height of $300 \mathrm{~mm}$ and a diameter of $150 \mathrm{~mm}$ are used in compliance with the ASTM C470 standards. They are cast from the same batch of NSC-4.75 mix and compacted mechanically using a hand tamping rod to prevent segregation and honeycombing. The sides of the moulds are stripped away after being left for $24 \mathrm{~h}$. All the specimens, i.e., $\mathrm{UC}$ and $\mathrm{MC}$ reference columns and $\mathrm{A}-\mathrm{B}$ and $\mathrm{X}-\mathrm{Y}$ column cores, are submerged in a curing water basin for 28 days. Figure 11 shows the A-B jacketed column specimens after curing, at which point they are ready to be tested.

2.4.3. Jacketing Using UHPFRSCC. After the UHPFRSCC is cast in the timber moulds, the surfaces are smoothed by trowelling. Three standard test cylinders with a height of
$300 \mathrm{~mm}$ and a diameter of $150 \mathrm{~mm}$ are used in compliance with the ASTM C470 standards. They are cast from the same batch of UHPFRSCC mix without manual compaction (as it is self-compacting concrete). The sides of the moulds are stripped away after being left for $24 \mathrm{~h}$. The X-Y jacketed column specimens are submerged in a curing water basin for 28 days. Three other standard test cylinders are cast with UHPFRSCC and submerged in a curing water basin for 28 days. Figure 12 shows the $\mathrm{X}-\mathrm{Y}$ jacketed column specimens after curing, at which point they are ready to be tested.

2.5. Testing of Column Specimens. The UC and MC reference columns and the A-B and X-Y jacketed column specimens are tested using a high-capacity compression testing machine (with code number C109N and supplied by Matest Company for material testing). The machine configuration is changed to an elastic system to enable the testing of compressive strength versus the axial displacement in compliance with the ASTM C470 standards, as discussed in the following section.

\subsubsection{Ultimate Load-Carrying Capacity of Column} Specimens. After ending the curing period, the UC and MC reference columns and A-B and X-Y jacketed column specimens are kept in a dry place for 10-15 min to attain the surface dry condition. Loose sand grains or incrustations are removed from the contact faces with testing machine platens.

The column specimens are then located carefully in the testing machine to ensure the vertical concentricity (uniaxial) of the applied compressive load. Then, the test is performed by the hydraulic machine with $3000 \mathrm{kN}$ compression testing capacity.

All column specimens are tested under a monotonically small loading rate of approximately $6 \mathrm{kN} / \mathrm{s}$ and a starting load of approximately $20 \mathrm{kN}$. The load is applied vertically at the top and bottom of the column specimens until failure and compression readings are recorded.

2.5.2. Axial Displacement of Column Specimens. The axial displacement of the $\mathrm{UC}$ and $\mathrm{MC}$ reference columns and $\mathrm{A}-\mathrm{B}$ and $\mathrm{X}-\mathrm{Y}$ jacketed column specimens is measured using the same compression testing machine. Three strain dial gauges with an accuracy of approximately $0.00254 \mathrm{~mm}$ are fixed at the midheight of the column (three faces) prior to testing. At each increment of $6 \mathrm{kN}$ axial compression load, the readings of axial displacement are recorded using the machine data acquisition system.

\section{Results and Discussion}

3.1. Compressive Strength of Reference Specimens. The compressive strength of the NSC is obtained by testing three standard test cylinders $(300 \mathrm{~mm}$ in height and $150 \mathrm{~mm}$ in diameter) at 28 days. Table 6 shows the average compressive strength of the three tested standard cylinders; the value is 
TABLE 5: Steel reinforcement testing results.

\begin{tabular}{lccccc}
\hline Bar type & Diameter $(\mathrm{mm})$ & Actual diameter $(\mathrm{mm})$ & Yield stress (MPa) & $\begin{array}{c}\text { Ultimate tensile } \\
\text { strength }(\mathrm{MPa})\end{array}$ & \% of elongation \\
\hline Transverse steel reinforcement & 2.5 & 2.5 & 240 & 276.8 & 31 \\
Main rebar & 8 & 8 & 360 & 414 & 20 \\
\hline
\end{tabular}

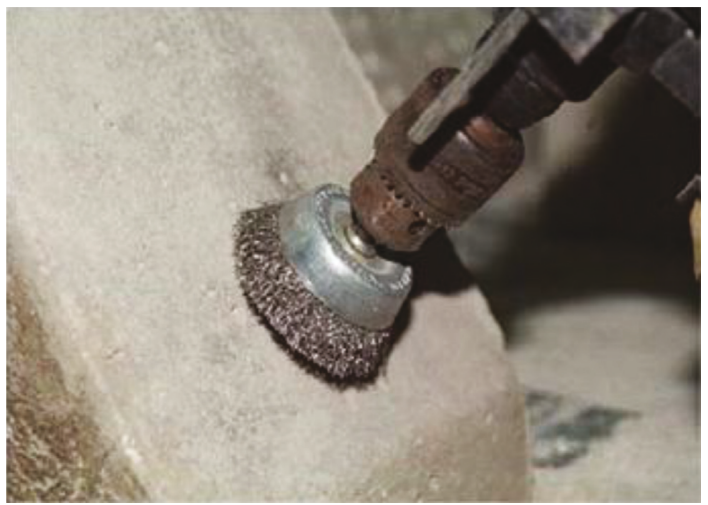

(a)

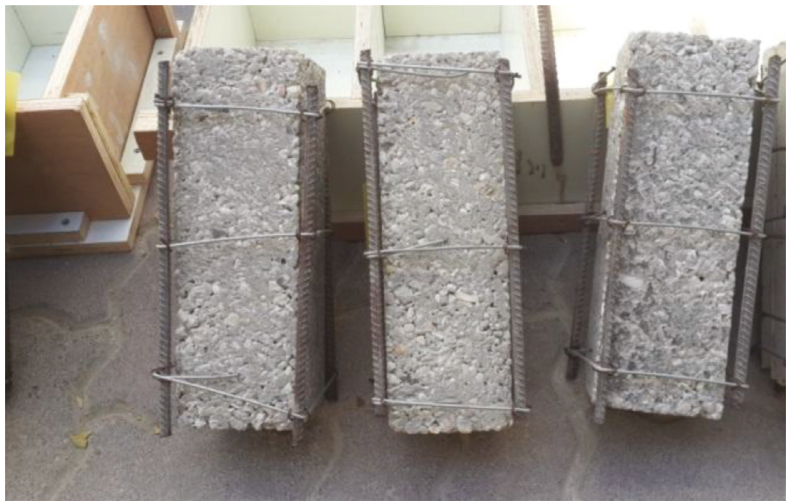

(b)

Figure 4: Preparation of the A-B-W and X-Y-W groups.

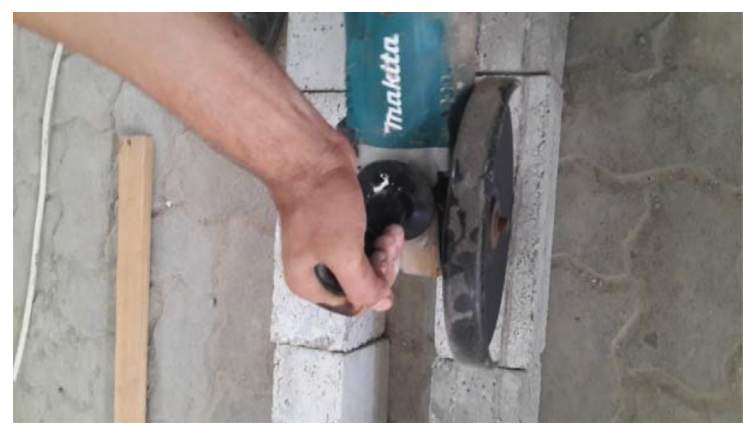

(a)

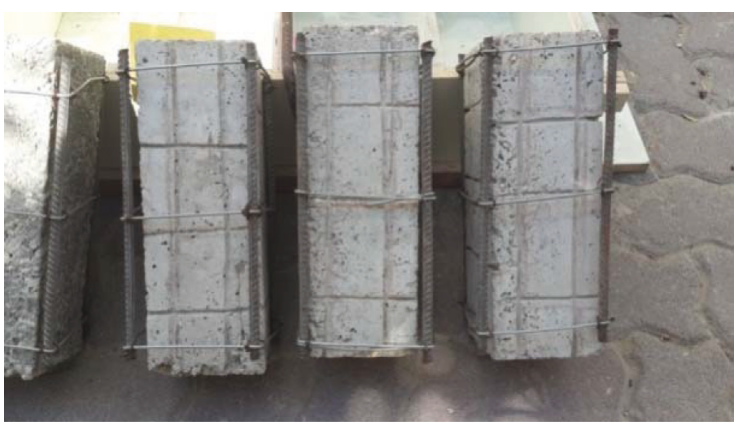

(b)

Figure 5: Preparation of the A-B-C and X-Y-C groups.

almost equal to the targeted NSC cylinder compressive strength of $25 \mathrm{MPa}$.

The compressive strength of the UHPFRSCC is obtained by testing three standard test cylinders $(300 \mathrm{~mm}$ in height and $150 \mathrm{~mm}$ in diameter) at 28 days. Table 6 shows the average compressive strength of the three tested standard cylinders. The value is close to the targeted UHPFRSCC cubic compressive strength of $120 \mathrm{MPa}$.

Figure 13 presents the obtained load-displacement diagrams of the UC, MC1, and MC2 column specimens. The UC, MC1, and MC2 reference columns reach their ultimate load-carrying capacities at an axial displacement of approximately $0.66 \mathrm{~mm}$; they have almost equal axial displacements at rupture points of $0.972,0.99$, and $1.02 \mathrm{~mm}$, respectively, possibly because they have similar steel reinforcement ratios and the same NSC mix.
3.2. A-B Jacketed Column Specimens (NSC-4.75 Jacket). The two jacket thicknesses of 25 and $35 \mathrm{~mm}$ result in a noticeable increase in the ultimate load-carrying capacity. The overall composite cross sections of the A-B jacketed column specimens are made of two different concrete mixes: the column cores are made of the NSC mix, whereas the outer jackets are made of the NSC-4.75 mix. Table 7 shows the effect of jacket thickness on the ultimate load-carrying capacity of the A-B group. The column cores are cast using the NSC mix with an unchanged cross section of $100 \mathrm{~mm} \times 100 \mathrm{~mm}$. Thus, the increase in cross-sectional area is obtained by applying the two jacket thicknesses.

The ratio of the jacket area of $\mathrm{B}-\mathrm{W} / \mathrm{A}-\mathrm{W}$ is 1.51 , whereas the corresponding ratio of ultimate load-carrying capacity is 1.38. This result shows a nearly direct proportional relation between jacket thickness and the ultimate load-carrying 


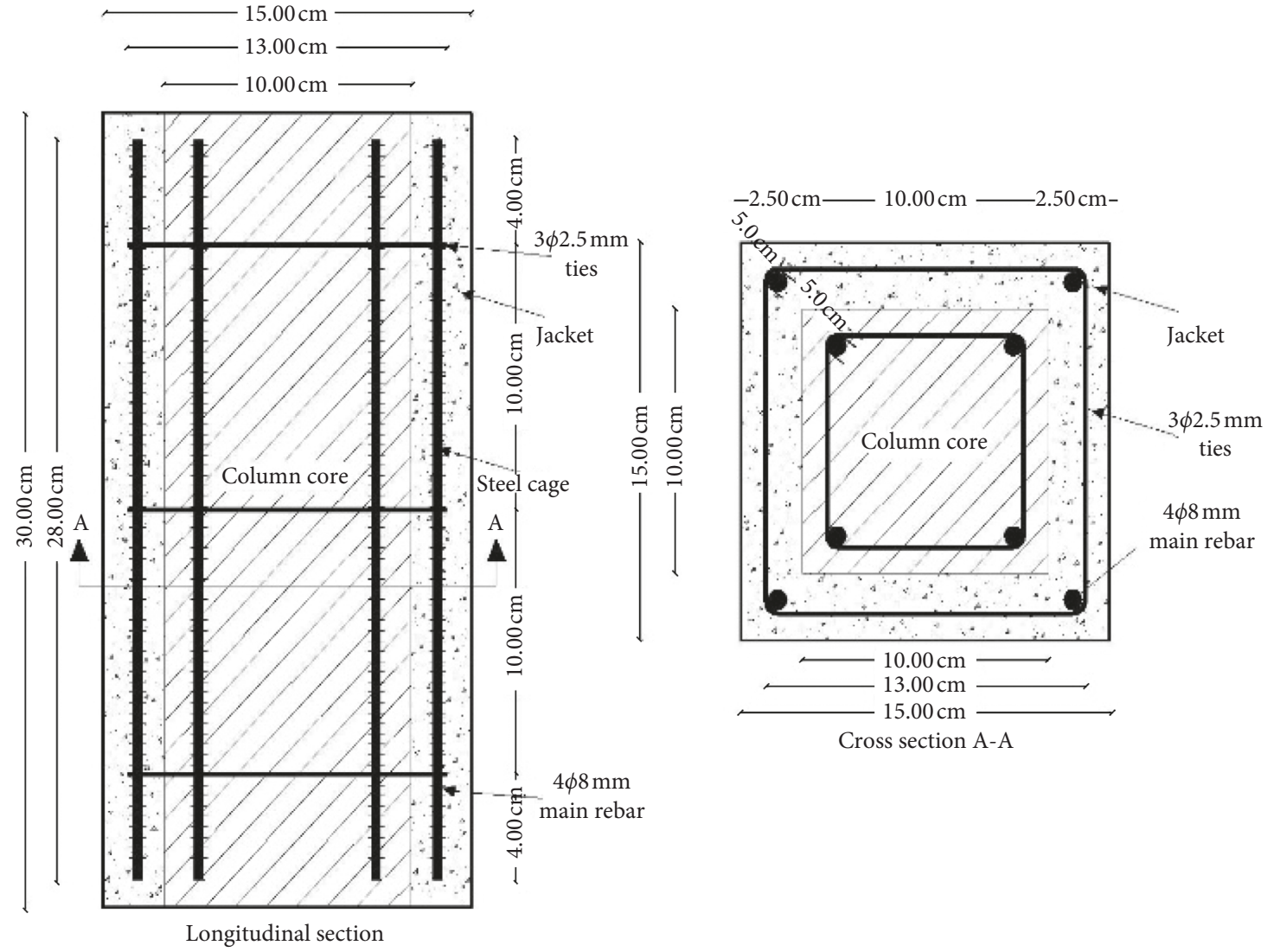

FIGURE 6: Geometry and reinforcement details of the A-W, X-W, A-C, and X-C groups.

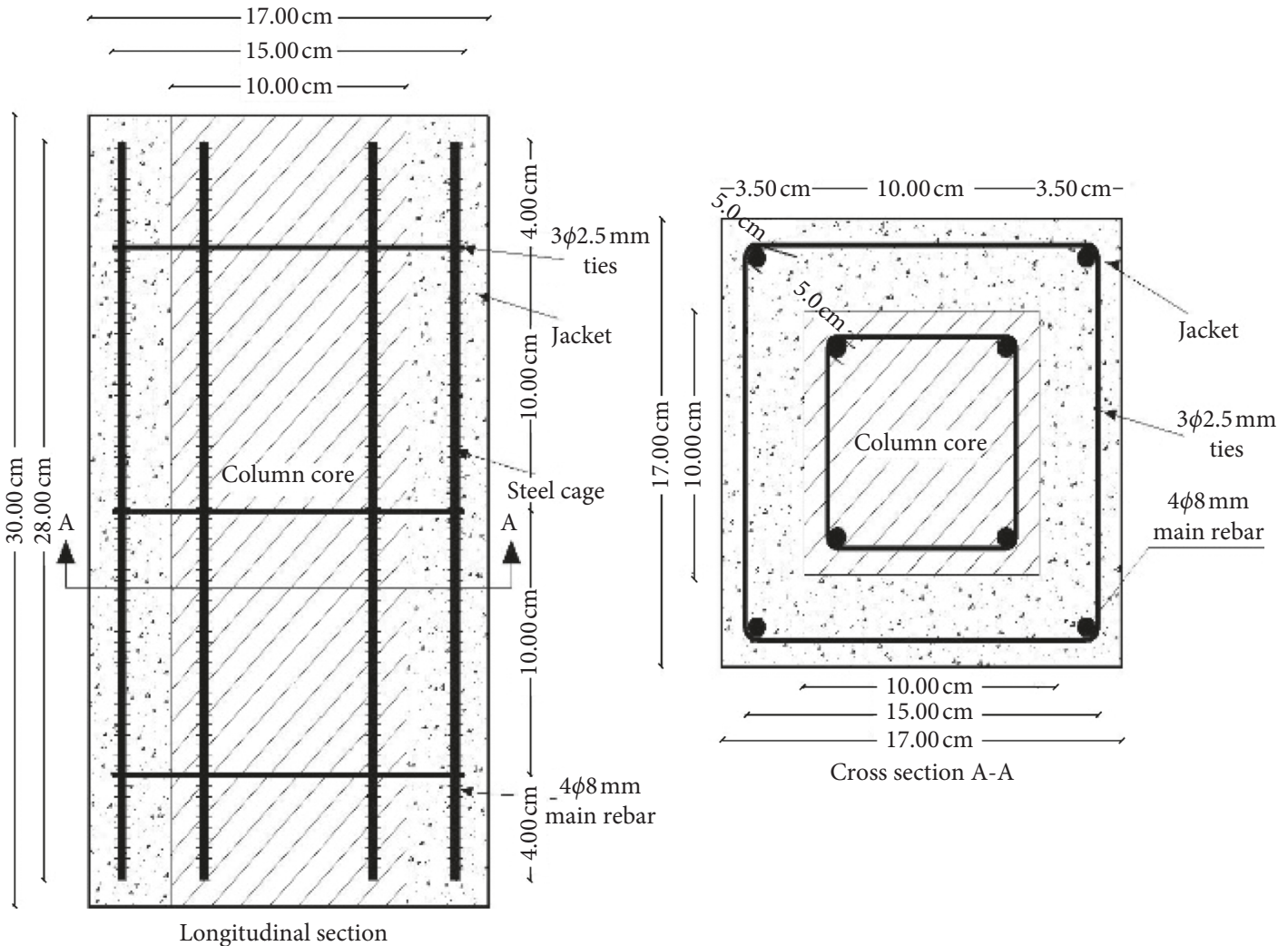

Figure 7: Geometry and reinforcement details of the B-W, Y-W, B-C, and Y-C groups. 


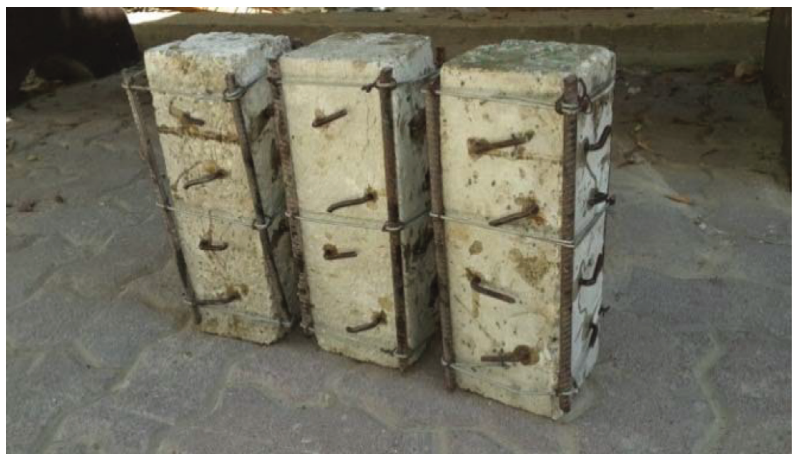

Figure 8: Preparation of the A-B-S and X-Y-S groups.

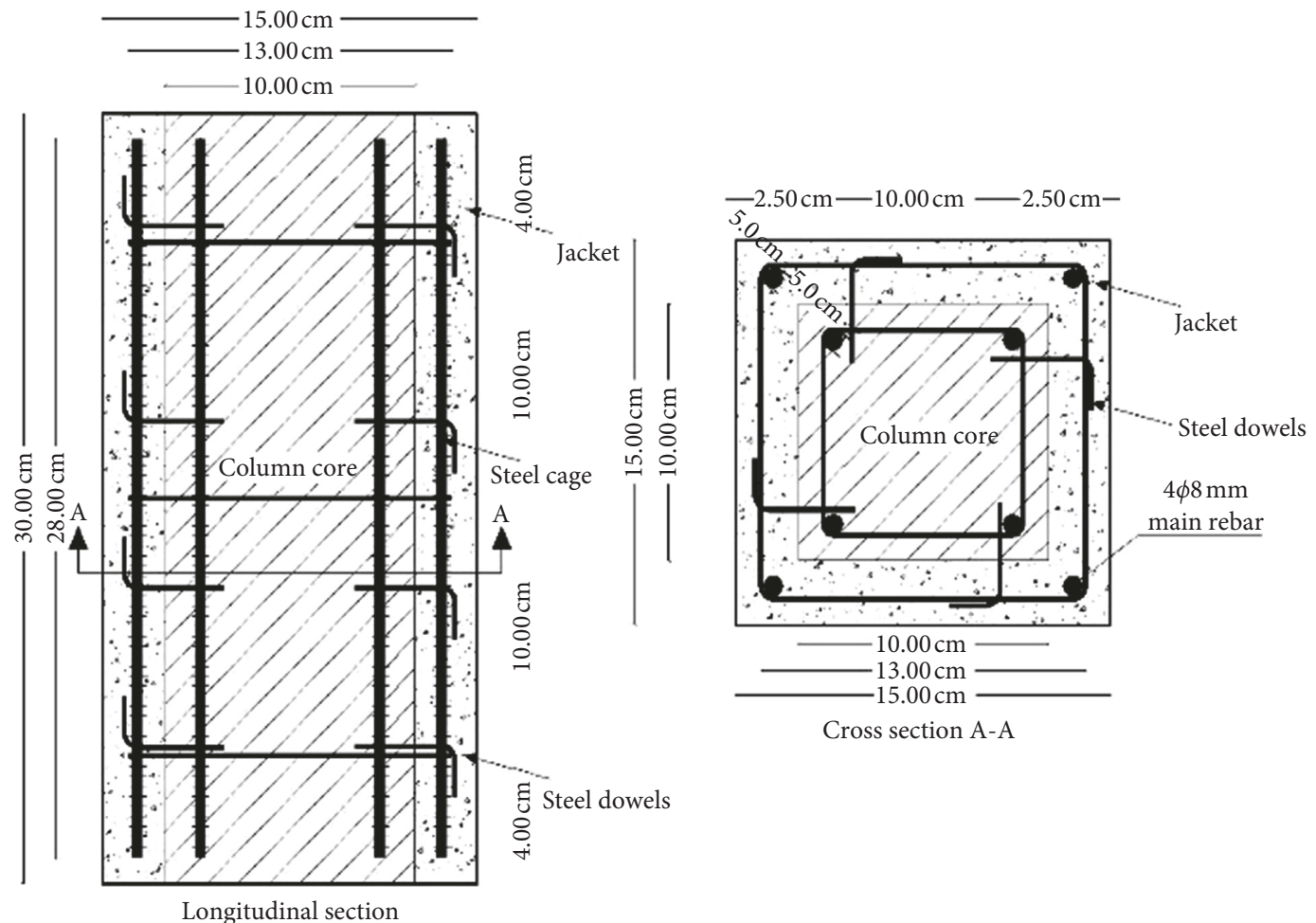

FIgURE 9: Geometry and reinforcement details of the A-S and X-S groups.

capacity of the A-B-W jacketed column specimens. The ratio of the jacket area of $\mathrm{B}-\mathrm{C} / \mathrm{A}-\mathrm{C}$ is 1.51 , whereas the corresponding ratio of ultimate load-carrying capacity is 1.26. This result shows a nearly direct proportional relation between jacket thickness and the ultimate load-carrying capacity of the A-B-C jacketed column specimens. The ratio of the jacket area of B-S/A-S is 1.51, whereas the corresponding ratio of ultimate load-carrying capacity is 1.32 . This result shows an almost direct proportional relation between jacket thickness and the ultimate load-carrying capacity of the A-B$\mathrm{C}$ jacketed column specimens.

Table 8 indicates that the A-W and B-W jacketed column specimens show an increase in ultimate load-carrying capacities of approximately 1.56 and 2.15 times those of the UC reference columns, respectively. Table 8 also shows that A-W and $\mathrm{B}-\mathrm{W}$ have an increase in ultimate load-carrying capacities of 1.08 and 0.95 times those of the corresponding $\mathrm{MC}$ reference columns, respectively. The results obtained are less than those obtained by Meda et al. [7], who strengthened a concrete column of cross section $(300 \mathrm{~mm} \times 300 \mathrm{~mm})$ with normal strength RC jacket that is $60 \mathrm{~mm}$ thick. Their results also showed that the ultimate capacities of the jacketed columns are more than 2.5 times those of the unjacketed columns. However, the results obtained are in good agreement with those obtained by Mourad and Shannag [16], who strengthened a concrete column of cross section $(150 \mathrm{~mm} \times 150 \mathrm{~mm})$ with ferrocement jackets of $20 \mathrm{~mm}$ jacket thickness after preloading one of them to $100 \%$ of 


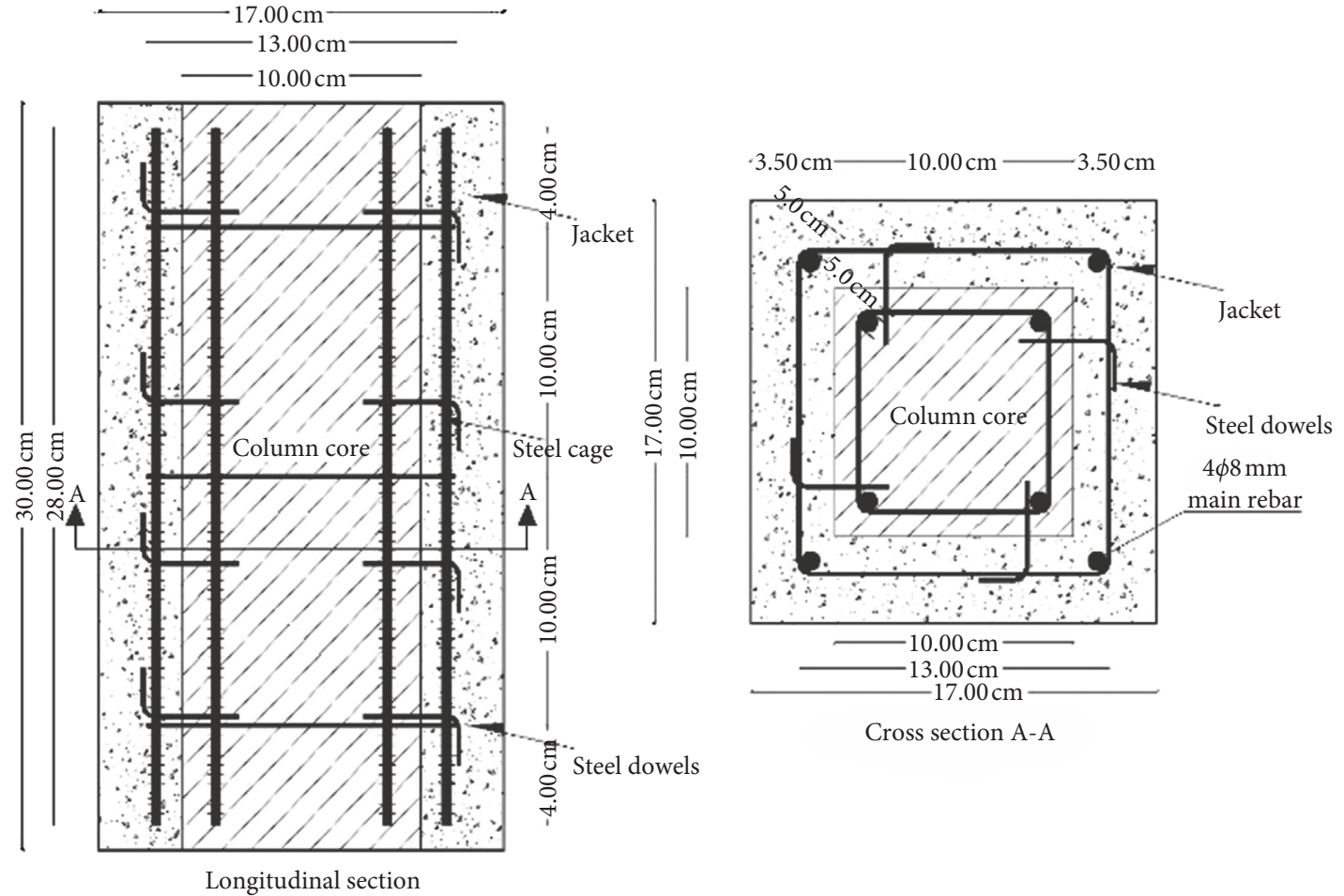

FIGURE 10: Geometry and reinforcement details of the B-S and Y-S groups.

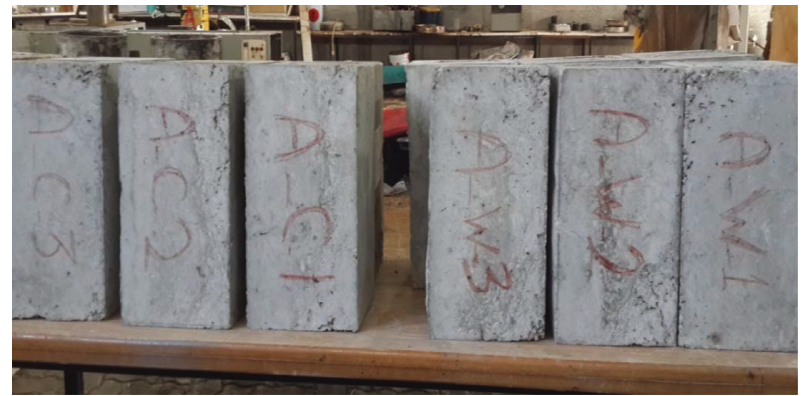

Figure 11: The A-B jacketed column specimens ready for testing.

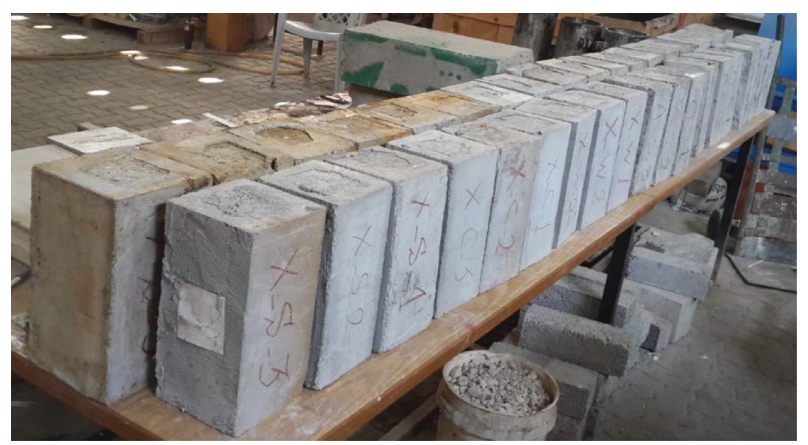

FIGURE 12: The X-Y jacketed column specimens ready for testing.

their ultimate axial strength. Strengthening the failed column restored its original capacity with similar axial stiffness and minimal ductility.
TABLE 6: Compression test results of NSC and UHPFRSCC.

\begin{tabular}{lcc}
\hline Mix type & Notation & Cylinder compressive strength $S(\mathrm{MPa})$ \\
\hline \multirow{4}{*}{ NSC } & S1 & 27.1 \\
& S2 & 25.3 \\
& S3 & 26.9 \\
& Average & 26.4 \\
\hline \multirow{4}{*}{ UHPFRSCC } & S1 & 103.2 \\
& S2 & 106.3 \\
& S3 & 107.6 \\
& Average & 105.7 \\
\hline
\end{tabular}

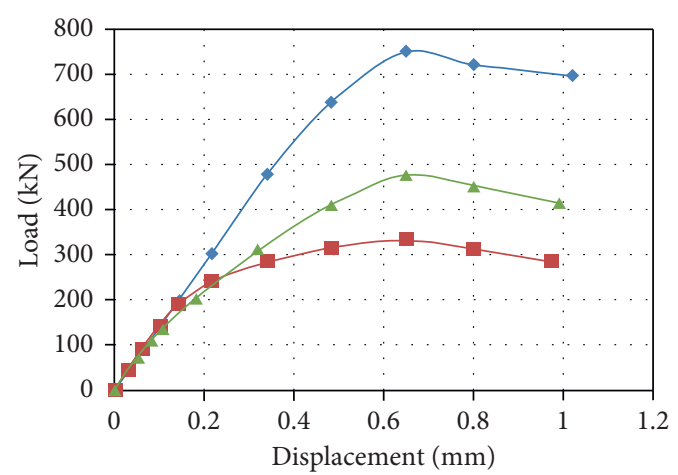

$$
\rightarrow \text { MC2 }
$$

FIgURE 13: Load-displacement diagrams of UC, MC1, and MC2 reference columns. 
TABLE 7: Ultimate load-carrying capacities for A-B jacketed column specimens.

\begin{tabular}{lcccc}
\hline Notation & $P_{\mathrm{u}}(\mathrm{kN})$ & Column sectional area & Column core area $\left(\mathrm{cm}^{2}\right)$ & Jacket area $\left(\mathrm{cm}^{2}\right)$ \\
\hline A-W & 517 & $(15 \mathrm{~cm} \times 15 \mathrm{~cm}) 225 \mathrm{~cm}^{2}$ & 100 & 125 \\
B-W & 713 & $(17 \mathrm{~cm} \times 17 \mathrm{~cm}) 289 \mathrm{~cm}^{2}$ & & 189 \\
B-W/A-W & 1.38 & $(15 \mathrm{~cm} \times 15 \mathrm{~cm}) 225 \mathrm{~cm}^{2}$ & 100 & 1.51 \\
A-C & 642 & $(17 \mathrm{~cm} \times 17 \mathrm{~cm}) 289 \mathrm{~cm}^{2}$ & & 125 \\
B-C & 812 & & & 189 \\
B-C/A-C & 1.26 & $(15 \mathrm{~cm} \times 15 \mathrm{~cm}) 225 \mathrm{~cm}^{2}$ & 100 & 1.51 \\
A-S & 653 & $(17 \mathrm{~cm} \times 17 \mathrm{~cm}) 289 \mathrm{~cm}^{2}$ & & 189 \\
B-S & 859 & & & 1.51 \\
B-S/A-S & 1.32 & & & \\
\hline
\end{tabular}

TABLE 8: Increases in A-B ultimate load-carrying capacity with respect to UC and MC.

\begin{tabular}{|c|c|c|c|c|c|c|}
\hline \multirow{2}{*}{$\begin{array}{l}\mathrm{A} \\
\mathrm{UC}, P_{\mathrm{u}}(\mathrm{kN})\end{array}$} & \multicolumn{2}{|c|}{ B } & \multicolumn{2}{|c|}{$\mathrm{C}$} & \multirow{2}{*}{$\mathrm{C} / \mathrm{A}$} & \multirow{2}{*}{$\mathrm{C} / \mathrm{B}$} \\
\hline & $\mathrm{MC}$ & $P_{\mathrm{u}}(\mathrm{kN})$ & A-B & $P_{\mathrm{u}}(\mathrm{kN})$ & & \\
\hline \multirow{6}{*}{331} & MC1 & 478 & A-W & 517 & 1.56 & 1.08 \\
\hline & MC2 & 751 & B-W & 713 & 2.15 & 0.95 \\
\hline & $\mathrm{MC1}$ & 478 & $A-C$ & 642 & 1.94 & 1.34 \\
\hline & MC2 & 751 & B-C & 812 & 2.54 & 1.12 \\
\hline & MC1 & 478 & A-S & 653 & 1.97 & 1.37 \\
\hline & MC2 & 751 & B-S & 859 & 2.6 & 1.14 \\
\hline
\end{tabular}

The results of the current research also indicate that the A-C and B-C jacketed column specimens show increases in ultimate load-carrying capacities of 1.94 and 2.54 times those of the UC reference columns, respectively. Table 8 also presents that $\mathrm{A}-\mathrm{C}$ and $\mathrm{B}-\mathrm{C}$ gain a significant increase in ultimate load-carrying capacities of 1.34 and 1.12 times those of the corresponding MC reference columns, respectively. The obtained results match those stated by Meda et al. [7] and Mourad and Shannag [16]; meanwhile, using scarification improves ultimate load-carrying capacity relative to mechanical wire brushing. The A-S and B-S jacketed column specimens show an increase in ultimate load-carrying capacities of 1.97 and 2.60 times those of the UC reference columns, respectively. Table 8 displays that A-S and B-S gain a significant increase in ultimate load-carrying capacities of 1.37 and 1.14 times those of the corresponding MC reference columns, respectively. These results are in good agreement with those obtained by Meda et al. [7] and Mourad and Shannag [16]; however, the current research indicates that using shear studs is the best method for improving ultimate load-carrying capacity.

The maximum measured axial displacements (axial displacements at rupture) of the UC and MC reference columns and A-B jacketed column specimens are compared in Table 9. The A-B-W jacketed column specimens gain a minimal increase in axial displacements at rupture relative to the UC and $\mathrm{MC}$ reference columns. This result is attributed to the use of NSC in jacketing, in addition to some enhancements to the concrete mix. Moreover, the A-B-C jacketed column specimens gain a minimal increase in axial displacements at rupture relative to the $\mathrm{UC}$ and $\mathrm{MC}$ reference columns. This result is attributed to the use of NSC in jacketing.

The column cores are repaired and strengthened using NSC-4.75 jacketing by applying the three jacketing methods.
A-B-W, A-B-C, and A-B-S show improved ultimate loadcarrying capacities, especially when compared with the UC and $\mathrm{MC}$ reference columns. Figures 14 and 15 show no significant differences in the results of the ultimate loadcarrying capacities of A-B-W, A-B-C, and A-B-S. The rate of increase in ultimate load-carrying capacity is almost similar to the increase in jacket thickness. The ultimate loadcarrying capacities of A-B-W, A-B-C, and A-B-S increase to approximately twice those of the corresponding $\mathrm{UC}$ reference columns and have no significant increase relative to the MC reference columns. Figures 14 and 15 also show that A-S and B-S have the maximum axial displacement values, which indicate the best ductility.

The results of using the three methods of surface roughening for good bonding between the specimens' cores and jackets reveal that using shear studs is the best among the three methods.

3.3. X-Y Jacketed Column Specimens (UHPFRSCC Jacket). The overall composite cross sections of the $\mathrm{X}-\mathrm{Y}$ jacketed column specimens are made of two different concrete mixes: the column cores are made of the NSC mix, whereas the outer jackets are made of the UHPFRSCC mix. Table 10 presents the average ultimate load-carrying capacity of X-Y.

The same table shows the effect of jacket thicknesses on $\mathrm{X}-\mathrm{Y}-\mathrm{W}$ 's ultimate load-carrying capacity. The ratio of the jacket area of $\mathrm{X}-\mathrm{W} / \mathrm{Y}-\mathrm{W}$ is 1.51 , whereas the corresponding ratio of ultimate load-carrying capacity is 1.27 . This result shows an almost direct proportional relation between jacket thickness and the ultimate load-carrying capacity of the $\mathrm{X}-\mathrm{Y}-\mathrm{W}$ jacketed column specimens. Table 10 shows the effect of jacket thicknesses on X-Y-C's ultimate loadcarrying capacity. The column cores are cast using the 
TABLE 9: Increases in A-B maximum axial displacement with respect to UC and MC.

\begin{tabular}{|c|c|c|c|c|c|c|}
\hline \multirow{2}{*}{$\begin{array}{l}\text { A } \\
\mathrm{UC} \text {, axial displacement } \\
\text { at failure }(\mathrm{mm})\end{array}$} & \multirow[b]{2}{*}{$\mathrm{MC}$} & \multicolumn{2}{|l|}{ B } & $\mathrm{C}$ & \multirow[b]{2}{*}{$\mathrm{C} / \mathrm{A}$} & \multirow[b]{2}{*}{$\mathrm{C} / \mathrm{B}$} \\
\hline & & Axial displacement at failure (mm) & A-B & Axial displacement at failure $(\mathrm{mm})$ & & \\
\hline \multirow{6}{*}{0.972} & $\mathrm{MC} 1$ & 0.99 & A-W & 0.99 & 1.02 & 1 \\
\hline & MC2 & 1.02 & $\mathrm{~B}-\mathrm{W}$ & 1.11 & 1.05 & 1.14 \\
\hline & $\mathrm{MC} 1$ & 0.99 & $\mathrm{~A}-\mathrm{C}$ & 1.02 & 1.05 & 1.03 \\
\hline & MC2 & 1.02 & $\mathrm{~B}-\mathrm{C}$ & 1.14 & 1.07 & 1.17 \\
\hline & MC1 & 0.99 & A-S & 1.05 & 1.08 & 1.06 \\
\hline & MC2 & 1.02 & B-S & 1.2 & 1.23 & 1.18 \\
\hline
\end{tabular}

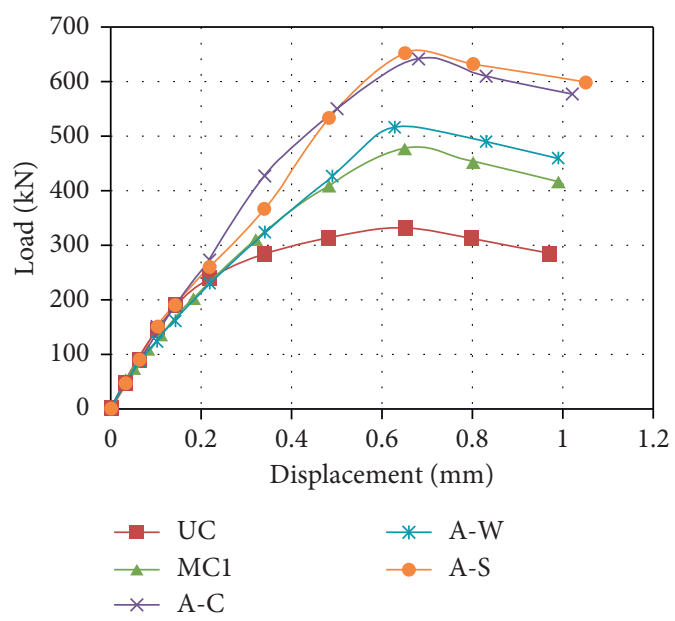

FIgURE 14: Average load-displacement diagram of A-(W-C-S) with respect to $\mathrm{UC}$ and $\mathrm{MC1}$.

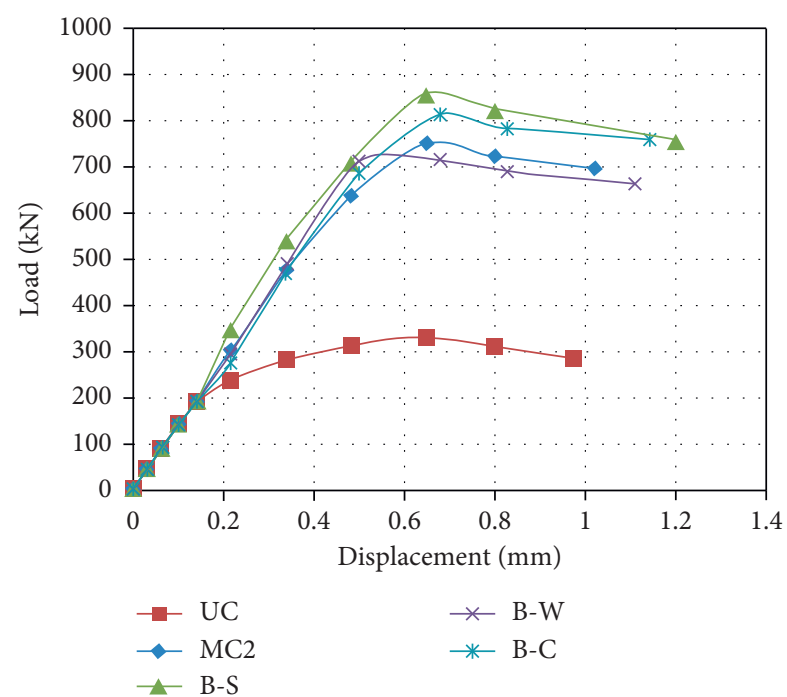

Figure 15: Average load-displacement diagram of B-(W-C-S) with respect to UC and MC2.

NSC mix with an unchanged cross section of $100 \mathrm{~mm} \times 100 \mathrm{~mm}$. Thus, the increase in cross-sectional area is obtained by applying several jacket thicknesses, almost similar to the obtained X-Y-W results. The ratio of the jacket area of $\mathrm{X}-\mathrm{C} / \mathrm{Y}-\mathrm{C}$ is 1.51 , whereas the corresponding ratio of ultimate load-carrying capacity is 1.34 . This result confirms the almost direct proportional relation between jacket thickness and the ultimate load-carrying capacity of the $\mathrm{X}-\mathrm{Y}-\mathrm{C}$ jacketed column specimens; the same results are obtained with respect to the $\mathrm{X}-\mathrm{Y}-\mathrm{W}$ jacketed column specimens. The ratio of the jacket area of X-S/Y-S is 1.51, whereas the corresponding ratio of ultimate load-carrying capacity is 1.32 . This result shows the almost direct proportional relation between jacket thickness and the ultimate load-carrying capacity of the X-Y-S jacketed column specimens; the same results are obtained with respect to the X-Y-W and X-Y-C jacketed column specimens.

Table 11 indicates that the $\mathrm{X}-\mathrm{W}$ and $\mathrm{Y}-\mathrm{W}$ jacketed column specimens show a substantial increase in ultimate load-carrying capacities of 2.67 and 3.70 times those of the UC reference columns, respectively. Table 11 also presents that $\mathrm{X}-\mathrm{W}$ and $\mathrm{Y}-\mathrm{W}$ gain a significant increase in ultimate load-carrying capacities of 1.85 and 1.63 times those of the corresponding $\mathrm{MC}$ reference columns, respectively. These results are less than those obtained by Meda et al. [7], who strengthened a concrete column of cross section $(300 \mathrm{~mm} \times 300 \mathrm{~mm})$ with a high-performance fibre RC jacket with $30 \mathrm{~mm}$ thickness. This study found that the ultimate load capacities of jacketed columns are more than four times those of unjacketed columns. In the present study, adopting a UHPFRSCC steel-reinforced jacket enhances the lateral confinement of the column specimens and thus increases the ability to sustain additional compression loads. The X-C and Y-C jacketed column specimens show considerably large increases in ultimate load-carrying capacities of 2.89 and 3.87 times those of the UC reference columns, respectively. Table 11 also shows that $\mathrm{X}-\mathrm{C}$ and $\mathrm{Y}-\mathrm{C}$ almost double their ultimate load-carrying capacities relative to the corresponding MC reference columns. The obtained results are less than those obtained by Meda et al. [7], who strengthened a concrete column of cross section $(300 \mathrm{~mm} \times 300 \mathrm{~mm})$ with a high-performance fibre RC jacket with $30 \mathrm{~mm}$ thickness. This study found that the ultimate capacities of the jacketed columns are more than four times those of unjacketed columns. These results are primarily attributed to the use of strengthening by the jacketing method instead of the repairing and strengthening jacketing method for predamaged RC columns. Meanwhile, using scarification improves ultimate load-carrying capacity relative to mechanical wire brushing. The X-S and Y-S 
TABLE 10: Ultimate load-carrying capacities for X-Y jacketed column specimens.

\begin{tabular}{lcccc}
\hline Notation & $P_{\mathrm{u}}(\mathrm{kN})$ & Column sectional area & Column core area $\left(\mathrm{cm}^{2}\right)$ & Jacket area $\left(\mathrm{cm}^{2}\right)$ \\
\hline X-W & 883 & $(15 \mathrm{~cm} \times 15 \mathrm{~cm}) 225 \mathrm{~cm}^{2}$ & 100 & 125 \\
Y-W & 1224 & $(17 \mathrm{~cm} \times 17 \mathrm{~cm}) 289 \mathrm{~cm}^{2}$ & & 189 \\
Y-W/X-W & 1.27 & $(15 \mathrm{~cm} \times 15 \mathrm{~cm}) 225 \mathrm{~cm}^{2}$ & 100 & 1.51 \\
X-C & 956 & $(17 \mathrm{~cm} \times 17 \mathrm{~cm}) 289 \mathrm{~cm}^{2}$ & & 125 \\
Y-C & 1280 & & & 189 \\
Y-C/X-C & 1.34 & $(15 \mathrm{~cm} \times 15 \mathrm{~cm}) 225 \mathrm{~cm}^{2}$ & 100 & 1.51 \\
X-S & 1030 & $(17 \mathrm{~cm} \times 17 \mathrm{~cm}) 289 \mathrm{~cm}^{2}$ & & 189 \\
Y-S & 1356 & & & 1.51 \\
Y-S/X-S & 1.32 & & & \\
\hline
\end{tabular}

TABLE 11: Increases in X-Y ultimate load-carrying capacities with respect to UC and MC.

\begin{tabular}{|c|c|c|c|c|c|c|}
\hline \multirow{2}{*}{$\begin{array}{l}\text { A } \\
\mathrm{UC}, P_{\mathrm{u}}(\mathrm{kN}) \\
\end{array}$} & \multicolumn{2}{|c|}{ B } & \multicolumn{2}{|c|}{$\mathrm{C}$} & \multirow{2}{*}{$\mathrm{C} / \mathrm{A}$} & \multirow{2}{*}{$\mathrm{C} / \mathrm{B}$} \\
\hline & MC & $P_{\mathrm{u}}(\mathrm{kN})$ & $\mathrm{X}-\mathrm{Y}$ & $P_{\mathrm{u}}(\mathrm{kN})$ & & \\
\hline \multirow{6}{*}{331} & MC1 & 478 & X-W & 883 & 2.67 & 1.85 \\
\hline & MC2 & 751 & Y-W & 1224 & 3.7 & 1.63 \\
\hline & MC1 & 478 & $\mathrm{X}-\mathrm{C}$ & 956 & 2.89 & 2 \\
\hline & MC2 & 751 & Y-C & 1280 & 3.87 & 1.7 \\
\hline & MC1 & 478 & X-S & 1030 & 3.11 & 2.15 \\
\hline & MC2 & 751 & Y-S & 1356 & 4.1 & 1.81 \\
\hline
\end{tabular}

jacketed column specimens show a huge increase in ultimate load-carrying capacities of 3.11 and 4.10 times those of the UC reference columns, respectively. Table 11 also reveals that X-S and Y-S gain significant increases in ultimate load-carrying capacities that are 2.15 and 1.81 times those of the corresponding MC reference columns, respectively. The obtained results are much better than those obtained by Meda et al. [7], who strengthened a concrete column of cross section $(300 \mathrm{~mm} \times 300 \mathrm{~mm})$ with a high-performance fibre RC jacket with $30 \mathrm{~mm}$ thickness. This study found that the ultimate capacities of jacketed columns are more than four times those of unjacketed columns. These results are attributed to the use of shear studs for bonding the column cores and their jacketing; this approach significantly enhances load capacity. The current research validates that using shear studs is the best method for improving ultimate load-carrying capacities.

The average load-displacement diagram is plotted for the $\mathrm{X}-\mathrm{Y}$ jacketed column specimens. The maximum measured axial displacements (axial displacements at rupture) of the UC and MC reference columns and X-W and Y-W jacketed column specimens are compared in Table 12. The X-Y-W jacketed column specimens gain almost a double increase in axial displacements at rupture with respect to the UC and $\mathrm{MC}$ reference columns. The axial displacements of the X-W and $\mathrm{Y}-\mathrm{W}$ jacketed column specimens are 1.98 and 2.04 times those of the UC reference columns, respectively. Furthermore, the axial displacements of both the X-W and Y-W jacketed column specimens are 1.94 times those of the corresponding $\mathrm{MC}$ reference columns. As shown in $\mathrm{Ta}-$ ble 12, the X-Y-C and X-Y-S jacketed column specimens gain almost a double increase in axial displacements at rupture with respect to the UC and MC reference columns.

Column cores are repaired and strengthened using UHPFRSCC jacketing by applying three jacketing types.
$\mathrm{X}-\mathrm{Y}-\mathrm{W}, \mathrm{X}-\mathrm{Y}-\mathrm{C}$, and $\mathrm{X}-\mathrm{Y}-\mathrm{S}$ show significantly improved ultimate load-carrying capacities, especially when compared with the UC and MC reference columns. Figures 16 and 17 also show no significant differences in the results of $\mathrm{X}-\mathrm{W}$, $\mathrm{X}-\mathrm{C}$, and $\mathrm{X}-\mathrm{S}$ and in those of $\mathrm{Y}-\mathrm{W}, \mathrm{Y}-\mathrm{C}$, and $\mathrm{Y}-\mathrm{S}$ in terms of ultimate load-carrying capacity. The rate of increase in ultimate load-carrying capacity is almost similar to the rate of increase in jacket thickness. The ultimate load-carrying capacities of X-Y-W, X-Y-C, and X-Y-S increase to about four and two times those of the corresponding UC and MC reference columns, respectively.

The results of using the three methods of surface roughness reveal that using shear studs is the best among the three methods.

Table 13 shows that the $\mathrm{X}-\mathrm{Y}$ jacketing type significantly increases the ultimate load-carrying capacities and high ductility of the jacketed column cores because of the application of steel fibres and steel-reinforced UHPFRSCC jackets. The significant increase in the axial displacements of $\mathrm{X}-(\mathrm{W}-\mathrm{C}-$ $\mathrm{S})$ and Y-(W-C-S) is attributed to the addition of $4 \%$ steel fibres in accordance with the weight of the UHPFRSCC mix; such a change results in improved material properties. The results of using the three methods of surface roughness also reveal that using shear studs is the best among the three methods.

\section{Conclusion}

The outcomes of the experimental study can be summarised as follows:

(i) Applying two jacket thicknesses of 25 and $35 \mathrm{~mm}$ with $\mathrm{A}-\mathrm{B}$ and $\mathrm{X}-\mathrm{Y}$ jacketing types considerably improves ultimate load-carrying capacity in almost a similar rate to the rate of increase in jacketing area. 
TABLE 12: Increases in X-Y maximum axial displacements with respect to UC and MC.

\begin{tabular}{|c|c|c|c|c|c|c|}
\hline \multirow{2}{*}{$\begin{array}{l}\text { A } \\
\mathrm{UC} \text {, axial displacement } \\
\text { at failure }(\mathrm{mm})\end{array}$} & \multirow[b]{2}{*}{$\mathrm{MC}$} & \multicolumn{2}{|l|}{ B } & $\mathrm{C}$ & \multirow[b]{2}{*}{$\mathrm{C} / \mathrm{A}$} & \multirow[b]{2}{*}{$\mathrm{C} / \mathrm{B}$} \\
\hline & & Axial displacement at failure (mm) & $\mathrm{X}-\mathrm{Y}$ & Axial displacement at failure (mm) & & \\
\hline \multirow{6}{*}{0.972} & $\mathrm{MC} 1$ & 0.99 & X-W & 1.92 & 1.98 & 1.94 \\
\hline & MC2 & 1.02 & Y-W & 1.98 & 2.04 & 1.94 \\
\hline & $\mathrm{MC} 1$ & 0.99 & $\mathrm{X}-\mathrm{C}$ & 1.92 & 1.98 & 1.94 \\
\hline & MC2 & 1.02 & $\mathrm{Y}-\mathrm{C}$ & 2.01 & 2.07 & 1.97 \\
\hline & $\mathrm{MC1}$ & 0.99 & $\mathrm{X}-\mathrm{S}$ & 1.98 & 2.04 & 2 \\
\hline & MC2 & 1.02 & Y-S & 2.04 & 2.09 & 2 \\
\hline
\end{tabular}

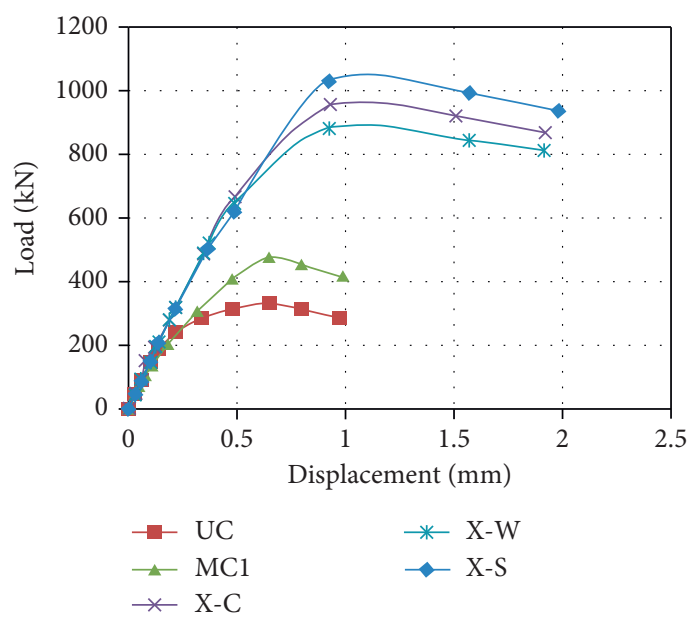

FIgURE 16: Average load-displacement diagram of X-(W-C-S) with respect to UC and MC1.

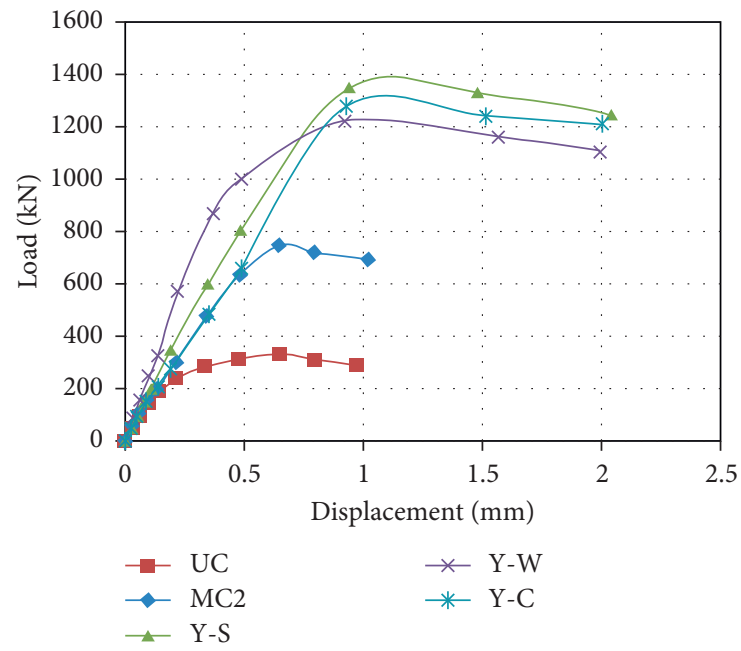

FIgURE 17: Average load-displacement diagram of $\mathrm{Y}-(\mathrm{W}-\mathrm{C}-\mathrm{S})$ with respect to UC and MC2.

(ii) Repairing and strengthening using UHPFRSCC and NSC-4.75 jackets significantly increases the ultimate load-carrying capacities and axial displacements of the specimens with respect to the UC and MC reference columns. The failure modes of the two jacketed column specimens are ductile and thus provide noticeable warning signs under loading before crushing and spalling.

(iii) Although repairing and strengthening RC columns using NSC-4.75 as a jacketing material is effective, UHPFRSCC is more effective due to the use of steel fibres. It also reduces the total strengthened column 
TABLE 13: Summary of the results for all tested column specimens.

\begin{tabular}{|c|c|c|c|c|c|}
\hline \# & & Description & Notation & $P_{\mathrm{u}}(\mathrm{kN})$ & Axial displacement $(\mathrm{mm})$ \\
\hline 1 & UC & njacketed reference column & UC & 331 & 0.972 \\
\hline 2 & \multirow{2}{*}{\multicolumn{2}{|c|}{ MC monolithically cast reference columns }} & $\mathrm{MC1}$ & 478 & 0.99 \\
\hline 3 & & & MC2 & 751 & 1.02 \\
\hline 4 & \multirow{6}{*}{ NSC-4.75 jacket, [A-B] } & \multirow{2}{*}{ Roughening surface by mechanical wire brushing } & A-W & 517 & 0.99 \\
\hline 5 & & & B-W & 713 & 1.11 \\
\hline 6 & & \multirow{2}{*}{ Roughening surface by mechanical scarification } & $\mathrm{A}-\mathrm{C}$ & 642 & 1.02 \\
\hline 7 & & & $\mathrm{~B}-\mathrm{C}$ & 812 & 1.14 \\
\hline 8 & & \multirow{2}{*}{ Bonding by using shear studs } & A-S & 653 & 1.05 \\
\hline 9 & & & B-S & 859 & 1.2 \\
\hline 10 & \multirow{6}{*}{ UHPFRSCC jacket, [X-Y] } & \multirow{2}{*}{ Roughening surface by mechanical wire brushing } & $\mathrm{X}-\mathrm{W}$ & 883 & 1.908 \\
\hline 11 & & & Y-W & 1224 & 1.989 \\
\hline 12 & & \multirow{2}{*}{ Roughening surface by mechanical scarification } & $\mathrm{X}-\mathrm{C}$ & 956 & 1.92 \\
\hline 13 & & & $\mathrm{Y}-\mathrm{C}$ & 1280 & 2.001 \\
\hline 14 & & \multirow{2}{*}{ Bonding by using shear studs } & $\mathrm{X}-\mathrm{S}$ & 1030 & 1.98 \\
\hline 15 & & & Y-S & 1356 & 2.04 \\
\hline
\end{tabular}

sections. The UHPFRSCC can flow better than NSC-4.75 in narrow sections without segregation or honeycombing problems.

(iv) The relationships between the applied loads and axial displacements of the tested column specimens are almost typical: a linear behaviour up to onethird of the ultimate load-carrying capacity followed by a nonlinear behaviour until failure.

(v) The slopes of the first parts of the plotted loaddisplacement curves of the UC and MC reference columns are almost the same, ultimately becoming steep during repairing and strengthening with the two jacketing types. Steep slopes mean that the modulus of elasticity of strengthened columns increases.

(vi) Applying the three methods of surface roughening, i.e., roughening by mechanical wire brushing, mechanical scarification, and using shear studs, to bond column cores and their jackets reveals that using shear studs is the best among the three methods.

\section{Data Availability}

The experimental data used to support the findings of this study are included in the article.

\section{Conflicts of Interest}

The authors declare that they have no conflicts of interest.

\section{Acknowledgments}

The authors gratefully acknowledge Eng. Mohammed Abu Naja as this paper was prepared from his MSc thesis [35]. Special thanks are due to the staff of the Islamic University of Gaza (IUG) Soil and Materials Lab for their help during the sample preparation and testing.

\section{References}

[1] P. A. Calderón, J. M. Adam, S. Ivorra, F. J. Pallarés, and E. Giménez, "Design strength of axially loaded RC columns strengthened by steel caging," Materials \& Design, vol. 30, no. 10, pp. 4069-4080, 2009.

[2] K. Fukuyama, Y. Higashibata, and Y. Miyauchi, "Studies on repair and strengthening methods of damaged reinforced concrete columns," Cement and Concrete Composites, vol. 22, no. 1, pp. 81-88, 2000.

[3] M. H. Allam, Strengthening of loaded columns by R.C. jackets, PhD thesis, Faculty of Engineering, Cairo University, Cairo, Egypt, 1995.

[4] D. Beaupré, "Bond strength of shotcrete repair," Shotcrete Magazine, vol. 1, no. 2, pp. 12-15, 1999.

[5] K. A.-D. I. Bsisu, "Retrofitting of square reinforced concrete columns subjected to concentric axial loading with steel jackets," CEO Al-Eman Housing Company, vol. 6, 2002.

[6] K. G. Vandoros and S. E. Dritsos, "Concrete jacket construction detail effectiveness when strengthening RC columns," Construction and Building Materials, vol. 22, no. 3, pp. 264-276, 2008.

[7] A. Meda, G. Plizzari, Z. Rinaldi, and G. Martinola, "Strengthening of R/C existing columns with high performance fiber reinforced concrete jacket," in Proceedings of the 2nd International Conference on Concrete Repair, Rehabilitation and Retrofitting, Cape Town, South Africa, 2009.

[8] G. Campione, M. Fossetti, C. Giacchino, and G. Minafò, "RC columns externally strengthened with RC jackets," Materials and Structures, vol. 47, no. 10, pp. 1715-1728, 2014.

[9] H. Can, "Partially jacketed (two, three, four sides) reinforced concrete column behaviour under uni-axial loading," Teknik Dergi-Tmmob Insaat Muhendisleri Odasi, vol. 6, pp. 337-342, 1995.

[10] M. Frangou, K. Pilakoutas, and S. Dritsos, "Structural repair/ strengthening of RC columns," Construction and Building Materials, vol. 9, no. 5, pp. 259-266, 1995.

[11] S. A. Sheikh, "Performance of concrete structures retrofitted with fibre reinforced polymers," Engineering Structures, vol. 24, no. 7, pp. 869-879, 2002.

[12] Y. T. Obaidat, S. Heyden, and O. Dahlblom, "The effect of CFRP and CFRP/concrete interface models when modelling 
retrofitted RC beams with FEM," Composite Structures, vol. 92, no. 6, pp. 1391-1398, 2010.

[13] M. H. Lai and J. C. M. Ho, "Confinement effect of ringconfined concrete-filled-steel-tube columns under uni-axial load," Engineering Structures, vol. 67, pp. 123-141, 2014.

[14] M. Yaqub and C. G. Bailey, "Repair of fire damaged circular reinforced concrete columns with FRP composites," Construction and Building Materials, vol. 25, no. 1, pp. 359-370, 2011.

[15] G. Campione, "Strength and ductility of R.C. columns strengthened with steel angles and battens," Construction and Building Materials, vol. 35, pp. 800-807, 2012.

[16] S. M. Mourad and M. J. Shannag, "Repair and strengthening of reinforced concrete square columns using ferrocement jackets," Cement and Concrete Composites, vol. 34, no. 2, pp. 288-294, 2012.

[17] U. Ersoy, A. T. Tankut, and R. Suleiman, "Behavior of jacketed columns," ACI Structural Journal, vol. 90, no. 3, pp. 288-293, 1993.

[18] B. Graybeal and J. Tanesi, "Durability of an ultrahighperformance concrete," Journal of Materials in Civil Engineering, vol. 19, no. 10, pp. 848-854, 2007.

[19] B. A. Tayeh, B. H. Abu Bakar, M. A. Megat Johari, and Y. L. Voo, "Mechanical and permeability properties of the interface between normal concrete substrate and ultra high performance fiber concrete overlay," Construction and Building Materials, vol. 36, pp. 538-548, 2012.

[20] A. P. Lampropoulos, S. A. Paschalis, O. T. Tsioulou, and S. E. Dritsos, "Strengthening of reinforced concrete beams using ultra high performance fibre reinforced concrete (UHPFRC)," Engineering Structures, vol. 106, pp. 370-384, 2016.

[21] L. K. Askar, B. A. Tayeh, B. H. A. Bakar, and A. M. Zeyad, "Properties of ultra-high performance fiber concrete (UHPFC) under different curing regimes," International Journal of Civil Engineering and Technology (IJCIET), vol. 8, no. 4, pp. 965-974, 2017.

[22] E. N. B. S. Júlio, F. A. B. Branco, and V. D. Silva, "Concrete-toconcrete bond strength. Influence of the roughness of the substrate surface," Construction and Building Materials, vol. 18, no. 9, pp. 675-681, 2004.

[23] A. A. Hallaq, B. A. Tayeh, and S. Shihada, "Investigation of the bond strength between existing concrete substrate and UHPC as a repair material," International Journal of Engineering and Advanced Technology (IJEAT), vol. 6, no. 3, pp. 210-217, 2017.

[24] B. A. Tayeh, B. H. A. Bakar, M. A. M. Johari, and Y. L. Voo, "Evaluation of bond strength between normal concrete substrate and ultra high performance fiber concrete as a repair material," Procedia Engineering, vol. 54, pp. 554-563, 2013.

[25] A. Meda, S. Mostosi, Z. Rinaldi, and P. Riva, "Corroded RC columns repair and strengthening with high performance fiber reinforced concrete jacket," Materials and Structures, vol. 49, no. 5, pp. 1967-1978, 2016.

[26] M. Chellapandian, S. S. Prakash, and A. Sharma, "Axial compression-bending interaction behavior of severely damaged RC columns rapid repaired and strengthened using hybrid FRP composites," Construction and Building Materials, vol. 195, pp. 390-404, 2019.

[27] B. A. Tayeh, B. H. Abu Bakar, M. A. Megat Johari, and A. M. Zeyad, "Microstructural analysis of the adhesion mechanism between old concrete substrate and UHPFC," Journal of Adhesion Science and Technology, vol. 28, no. 18, pp. 1846-1864, 2014.
[28] B. A. Tayeh, B. H. Abu Bakar, M. A. Megat Johari, and M. M. Ratnam, "Existing concrete textures: their effect on adhesion with fibre concrete overlay," Proceedings of the Institution of Civil Engineers-Structures and Buildings, vol. 167, no. 6, pp. 355-368, 2014.

[29] ACI 211.1-91, Standard Practice for Selecting Proportions for Normal, Heavyweight and Mass Concrete, American Concrete Institute, Farmington Hills, MI, USA, 1991.

[30] H. Rodrigues, P. Pradhan, A. Furtado, P. Rocha, and N. VilaPouca, "Structural repair and strengthening of rc elements with concrete jacketing," Strengthening and Retrofitting of Existing Structures, vol. 9, pp. 181-198, 2018.

[31] M. Arafa, S. Shihada, and A. Al Madhoun, "Mechanical properties of ultra high performance fiber reinforced self compacted concrete," International Journal of Engineering and Advanced Technology (IJEAT), vol. 3, 2013.

[32] M. Karmout, Mechanical Properties of Ultra High Performance Concrete Produced in Gaza Strip, The Islamic University of Gaza, Gaza, Palestine, 2009.

[33] K. N. Bakhsh, "Evaluation of bond strength between overlay and substrate in concrete repairs," Master Degree thesis, Royal Institute of Technology (KTH), Stockholm, Sweden, 2010.

[34] ASTM C192/C192M, Standard Practice for Making and Curing Concrete Test Specimens in the Laboratory, ASTM International, West Conshohocken, PA, USA, 2000.

[35] M. Abu Naja, "Repair of pre-damaged (RC) columns using cementitious repair materials," Master thesis, The Islamic University of Gaza, Gaza, Palestine, 2015. 


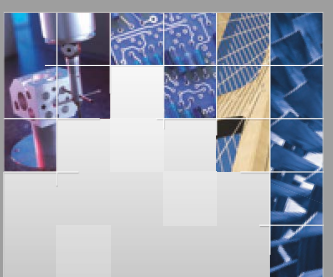

\section{Enfincering}
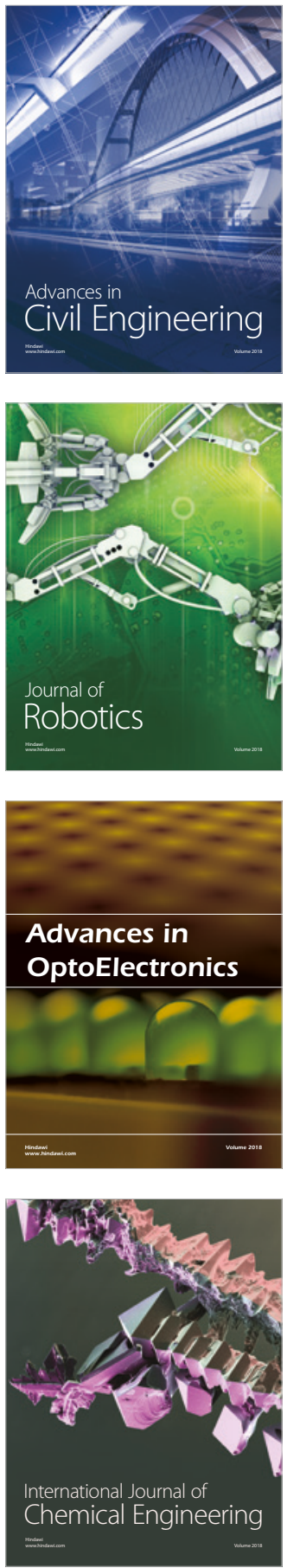

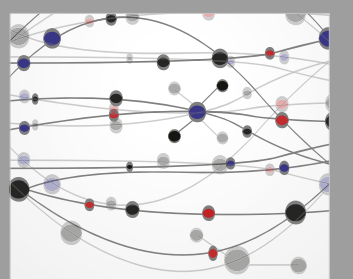

\section{Rotating \\ Machinery}

The Scientific World Journal

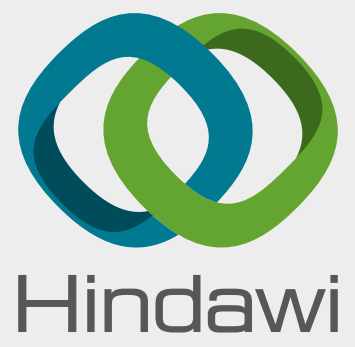

Submit your manuscripts at

www.hindawi.com
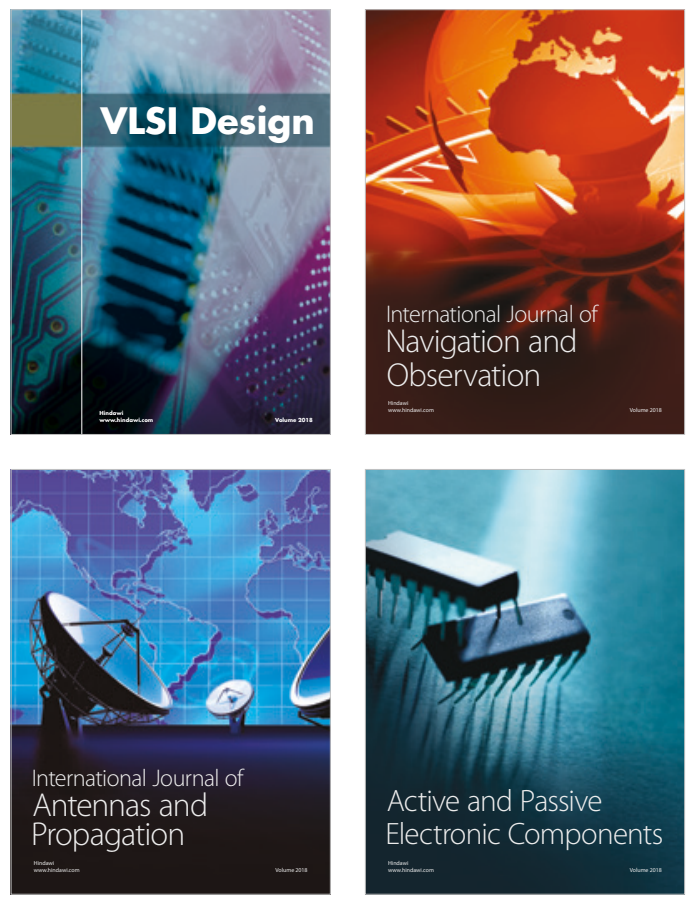
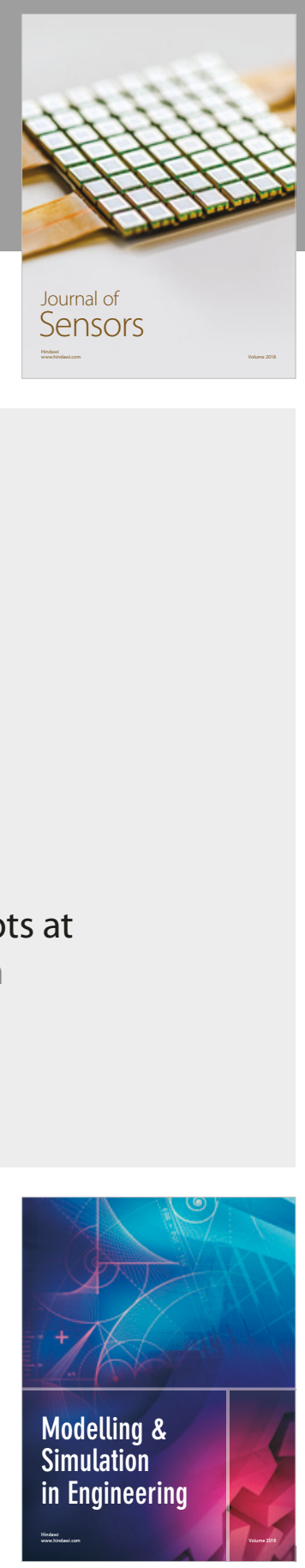

\section{Advances \\ Multimedia}
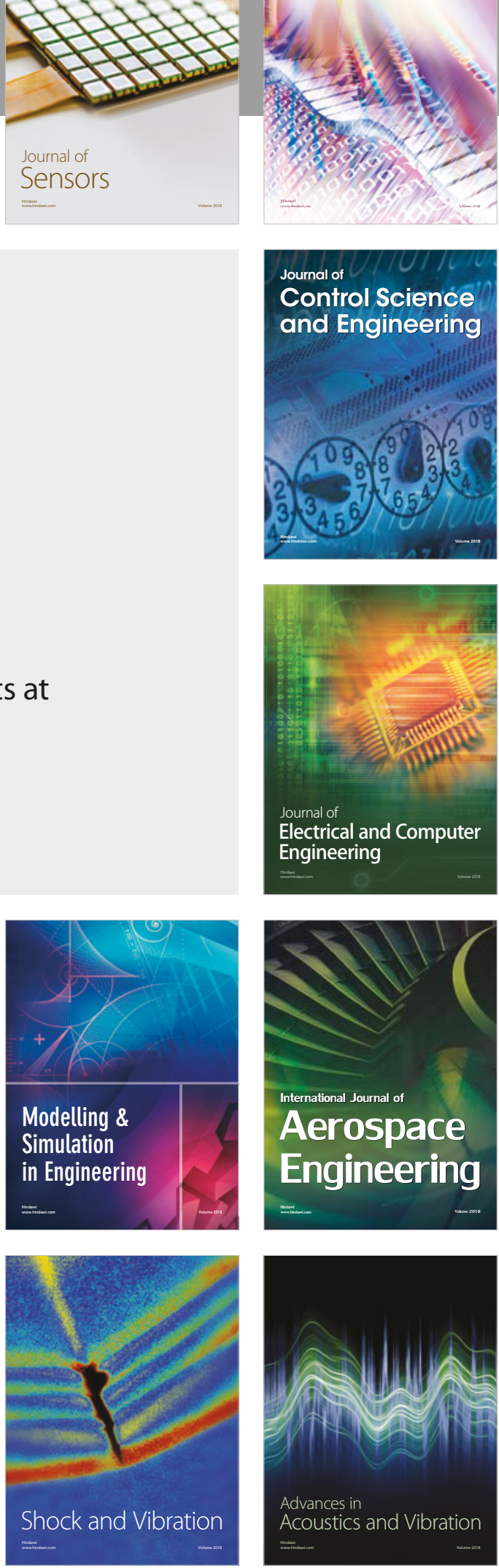